\title{
47. LIPIDS OF AN UPPER ALBIAN LIMESTONE, DEEP SEA DRILLING PROJECT SITE 465, SECTION 465A-38-31
}

\author{
P. A. Comet, J. McEvoy, S. C. Brassell, G. Eglinton, J. R. Maxwell, and I. D. Thomson, \\ Organic Geochemistry Unit, University of Bristol, School of Chemistry, Cantock's Close, Bristol BS8 1TS, England
}

\begin{abstract}
The lipids of an Albian carbonaceous limestone show evidence of high algal productivity. They contain a preponderance of chlorophyll derivatives, algal markers, and marine sterol distributions. The low percentages of lipids derived from terrestrial plant waxes and resins suggest that no major vegetated continental landmasses were present nearby. This agrees with the plate-tectonic reconstructions for the Albian of the northwest Pacific. However, as an exposed feature the Hess Rise may well have contributed the small amounts of terrestrial material found. The predominance of hopanoids over other polycyclic isoprenoids may indicate extensive bacterial activity at the time of sedimentation. Nevertheless, these bacteria have not extensively altered the algal lipid distribution. The association between high productivity, good lipid preservation, and bacterial activity is rationalized here in terms of an oxygenminimum zone, overlain by productive water masses.

Diagenesis has progressed to the medium stage, on the basis of lipid defunctionalization, the polycyclic isoprenoids being essentially present as hydrocarbons. However, late-stage diagenetic hydrogenation of sterenes and triterpenes has occurred only slightly, indicating that diagenesis is not as advanced as in the top zone of the Paris Basin. Backbone rearrangements of the steroidal alkenes have occurred to only a minimum extent.
\end{abstract}

\section{INTRODUCTION}

The free lipids (hydrocarbons, ketones, alcohols, acids, and porphyrins) of an upper Albian carbonaceous limestone from the Hess Rise (DSDP Section 465A-38-3) were investigated to evaluate (1) organic inputs, in an attempt to understand the conditions of deposition of the Lower Cretaceous Pacific "black shale" facies, and (2) the maturity of the sample.

The distribution of each functional group of compounds is described. The lipid components are also grouped into structural classes, whose proportions are held herein to be of paleoenvironmental importance and relatively free from diagenetic-maturational bias. Finally, some of the functional and(or) structural groups of compounds are markers for particular types of organisms, and these further clarify input problems.

In the preliminary survey, six samples (465-3-4, upper Paleocene; 465-10-3 and 465A-3-5, upper Maastrichtian; 465A-11-3, lower Maastrichtian; 465A-15-3, Upper Campanian-all nannofossil/foraminifer oozes465A-38-3, upper Albian limestone) were examined for visual kerogen by the use of acid dissolution. All but one sample were entirely acid-soluble; consequently, only this remaining sample (465A-38-3) was examined in detail.

\section{EXPERIMENTAL}

The experimental scheme used was similar to that of our previous DSDP investigations (Barnes et al., 1979; Brassell, Comet, Eglinton, McEvoy, et al., 1980) but differs in the following respects: (1) acid dissolution was used for a preliminary evaluative step in the analyses of these carbonate-rich samples, (2) Section 465A-38-3 was pulverized in a Tema disc mill because of its high degree of lithification, prior to

\footnotetext{
${ }^{1}$ Initial Reports of the Deep Sea Drilling Project, Volume 62.
}

sonication, and (3) for gas chromatography-mass spectrometry (GCMS) analyses, an INCOS 2300 data system was employed (Brassell, Gower, et al., 1980). In addition, the metalloporphyrin fractions were re-chromatographed on silica-gel $\mathrm{H}$ plates, using dichloromethane/toluene $(1: 8)$ as developer. Electronic spectra (UV/visible) were obtained on a Perkin-Elmer 552 spectrophotometer, in dichloromethane, using $1 \mathrm{~cm}$ ( $3 \mathrm{ml}$ capacity) quartz cells. Mass spectra for the metalloporphyrin fractions were obtained on a Finnigan 4000 spectrometer, using an INCOS 2300 data system, by direct-insertion probe. The scan cycle was 4 seconds, and the mass range was $\mathrm{m} / \mathrm{z}$ 50-650. Operating conditions were: source temperature $250^{\circ} \mathrm{C}$, electron energy $35 \mathrm{eV}$, emission current $350 \mu \mathrm{A}$, acceleration voltage $1.8 \mathrm{kV}$. Compound assignments were made from their individual mass spectra and GC retention data, with reference to authentic standards where possible. Mass fragmentography was used extensively to characterize homologous and pseudohomologous series (Wardroper et al., 1977; Brassell, Gower, et al., 1980), and to aid compound identifications. Each component was quantitated from its gas chromatographic response.

\section{RESULTS}

\section{Lithology and Palynology}

Section $465 \mathrm{~A}-38-3$ is an upper Albian, olive-gray, well-lithified, finely laminated limestone. A sub-sample $(\sim 5 \mathrm{~g})$, analyzed by the British Petroleum Co. Ltd., was $92.2 \%$ acid-soluble (carbonate), with an organic carbon content of $2.1 \%$. Visual examination of kerogen showed that the bulk of the organic matter is amorphous material of marine-algal origin. Numerous foraminifer linings were seen, but no dinoflagellate cysts were observed. Miospores are rare, suggesting only minor terrestrial input. The sample is immature; its autochthonous vitrinite reflectance $\left(\bar{R}_{\mathrm{o}}\right)$ is 0.33 .

\section{Aliphatic Hydrocarbons}

\section{Acyclic Components}

The $n$-alkanes in Section 465A-38-3 range from $\mathrm{C}_{15}$ to $\mathrm{C}_{34}$, with a CPI (odd/even carbon preference index) 
of 1.08 . The absolute concentrations of the individual homologs (quoted in ng/g dry weight of sediment) are shown in Figure 1. The $\mathrm{C}_{17}-\mathrm{C}_{21}$ homologs predominate. In general, $n$-alkane concentrations decrease with increasing carbon number, with the exception of nonacosane, which is more abundant than octacosane. No $n$-alkenes were detected. No monomethyl or other simple branched alkanes were detected in Section 465A38-3. In contrast, $2,6,10,14,19,23,27,31$-octamethyldotriacontane (lycopane, III) is the major alkane in the sample, whereas the other acyclic isoprenoids, 2,6,10trimethylpentadecane, pristane, phytane, 2,6,10,15,19pentamethyleicosane (I), and 2,6,10,15,19,23-hexamethyltetracosane (squalane, II) are all present as minor components (Fig. 1). The pristane-to-phytane ratio is 0.56 . Isoprenoid alkenes are present as trace components, but their low relative abundance precluded their identification.

\section{Cyclic Components}

Neither diterpenoid alkanes nor alkenes were detected in Section 465A-38-3. A wide range of $5 \alpha-$ and $5 \beta$-steranes were recognized (Table 1 ; Fig. 2), with $5 \alpha$-isomers predominating. The higher series homologs (i.e., $\mathrm{C}_{27}-\mathrm{C}_{30}$ ) were the major components. Individual 4-methylsteranes and $\beta \alpha$-diasteranes were identified, rather than compound series.

Hopanes ranging from $C_{27}$ to $C_{35}$ were recognized (Table 2). $\beta \beta$-hopanes are the dominant series, with $\beta \beta$ homohopane (XIId) the major component. $\alpha \beta$-hopanes are more abundant than $\beta \alpha$-hopanes, and, for the extended members $\left(C_{31}-C_{33}\right)$, their $22 R$ diastereoisomers greatly dominate the $22 \mathrm{~S}$ epimers.

The principal sterenes (Table 3) present were $\mathrm{C}_{27}-\mathrm{C}_{29}$ series of $\Delta^{4}$ and $\Delta^{5}$ isomers, the former isomers more abundant. The lack of reference spectra for $\Delta^{22}$-steradienes prevented the assignment of positions of unsaturation in their nuclei. A single 4-methyldiasterene (XIIIc) was recognized.

A series of $\Delta^{17(21)}$-hopenes ranging from $C_{27}$ to $C_{35}$ (excluding $\mathrm{C}_{28}$ and $\mathrm{C}_{34}$ ), and dominated by hop-17(21)ene (XIXc) was found (Table 4). 22R and $22 \mathrm{~S}$ epimers of the extended $\left(>\mathrm{C}_{31}\right)$ components were identified, with the $22 \mathrm{R}$ diastereoisomers more abundant. Four bisnorhopenes were tentatively identified from their mass

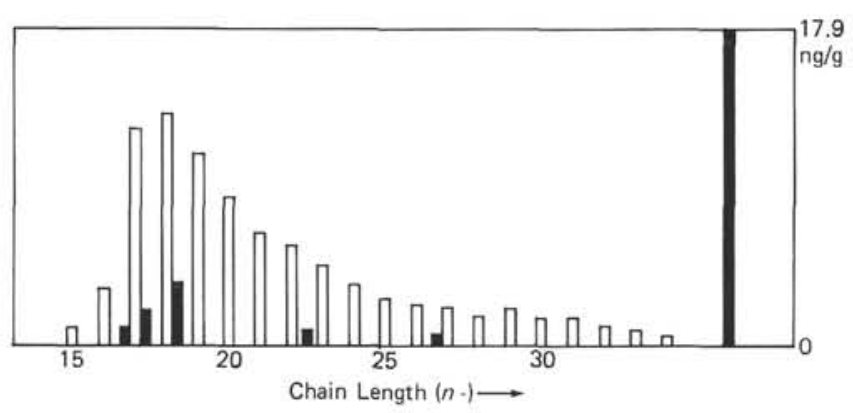

Figure 1. Distribution of acyclic alkanes in Section 465A-38-3. Hollow bars $=n$-alkanes. Solid bars $=$ acyclic isoprenoid alkanes (from left to right: $C_{18}, C_{19}$ [pristane], $C_{20}$ [phytane], $C_{25}[2,6,10$, 15,19-pentamethyleicosane], $\mathrm{C}_{30}$ [squalane], and $\mathrm{C}_{40}$ [lycopane]).
Table 1. Concentration of steranes in Section 465A-38-3.

\begin{tabular}{|c|c|c|c|}
\hline Component $^{\mathrm{a}}$ & Assignment ${ }^{\mathrm{b}}$ & Structure $^{c}$ & $\begin{array}{c}\text { Concentration } \\
(\mathrm{ng} / \mathrm{g})^{\mathrm{d}}\end{array}$ \\
\hline A & $5 \beta$-Androstane & IVa & 0.10 \\
\hline B & $5 \alpha$-Androstane & $\mathrm{Va}$ & 0.30 \\
\hline $\mathrm{c}$ & $5 \beta$-Pregnane & $\mathrm{IVb}$ & 0.05 \\
\hline D & $5 \alpha$-Pregnane & $\mathrm{Vb}$ & 0.26 \\
\hline E & 4-Methyl- $5 \alpha$-pregnane & VIb & 0.11 \\
\hline $\mathrm{F}$ & 20-Methyl-5 $\alpha$-pregnane & $\mathrm{Vc}_{\mathrm{c}}$ & 0.09 \\
\hline G & 20-Ethyl-5 $\alpha$-pregnane & $\mathrm{Vd}$ & 0.03 \\
\hline $\mathrm{H}$ & $5 \beta$-Cholane & IVe & 0.07 \\
\hline 1 & $5 \alpha$-Cholane & Ve & 0.26 \\
\hline $\mathrm{j}$ & $20 \mathrm{~S} \beta \alpha$-Diacholestane & VIIh & 0.13 \\
\hline $\mathrm{K}$ & 24-Methyl-5 $\alpha$-cholane & $\mathrm{Vf}$ & 0.06 \\
\hline $\mathrm{L}$ & 4-Methyl-5 $\alpha-24$-norcholestane & VIg & 0.18 \\
\hline M & 20R $\beta \alpha$-Diacholestane & VIIi & 0.12 \\
\hline $\mathrm{N}$ & $5 \beta$-Cholestane & IVi & 0.93 \\
\hline $\mathrm{o}$ & $5 \alpha$-Cholestane & $\mathrm{Vi}$ & 2.01 \\
\hline $\mathrm{P}$ & 24-Methyl-5 $\beta$-cholestane & IVj & 0.54 \\
\hline $\mathrm{Q}$ & 24-Methyl-5 $\alpha$-cholestane & $\mathrm{Vj}$ & 1.10 \\
\hline $\mathrm{R}$ & 24 -Ethyl-5 3 -cholestane & IVk & 1.34 \\
\hline s & 23,24-Dimethyl-5 $\alpha$-cholestane & $\mathrm{V}]$ & 0.71 \\
\hline$T$ & 24-Ethyl-5 $\alpha$-cholestane & Vk & 3.76 \\
\hline U & 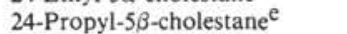 & $\mathrm{IVm}$ & 0.20 \\
\hline $\mathrm{V}$ & 24-Propyl-5 $\alpha$-cholestane $e^{e}$ & $\mathrm{Vm}$ & 1.15 \\
\hline
\end{tabular}

a See Figure 2 .

$\mathrm{b}$ Based on mass spectral interpretation, comparison with authentic standards, and $\mathrm{GC}$ retention values.

c See Appendix.

Dry weight of sediment.

e May be 24-isopropyl isomers.

spectra. In addition, neohop-13(18)-ene (XX); 22,29, 30-trisnorneohop-13(18)-ene, (XVIII); $\Delta^{7}-, \Delta^{8}-$, and $\Delta^{9(11)}$-fernenes (XXI); and very tentatively, arbor-9(11)ene (XXII) were recognized.

\section{Aromatic Hydrocarbons}

Among the aromatic hydrocarbons, the non-hopanoid polynuclear aromatic hydrocarbons were present in relatively minor amounts, except for perylene (XXIX) and methylperylene (XXX) (Table 5). Three diterpenoidal trienes of unknown structure (probably bisnorabietatrienes) were the dominant diterpenoids in the sample. The aromatic hopanoids (XXXI-XXXVII) were the major aromatic components. They occur as the full series of partially to fully aromatic compounds (Spyckerelle et al., 1977a, b). No aromatic components related to amyrin-type triterpenoids were detected.

\section{Ketones}

\section{Acyclic Components}

A series of $n$-alkan-2-ones, ranging from $\mathrm{C}_{14}$ to $\mathrm{C}_{29}$, maximizing at $C_{18}$, were found as minor components (Fig. 3); no odd-over-even preference was apparent (CPI value 0.64). 6,10,14-trimethylpentadecan-2-one (XXVIII), dominating the series of $n$-alkan-2-ones, was the only acyclic isoprenoid ketone detected.

\section{Cyclic Components}

Cyclic ketones were more abundant than acyclic components. Both steroidal and triterpenoidal ketones were detected, but several of these compounds could not be identified, because of the lack of reference mass spectra. Series $\left(C_{27}-C_{29}\right)$ of $5 \alpha$ - and $5 \beta$-stan-3-ones (Table 6), and ster-4-en-3-ones (Table 7), were present in similar con- 


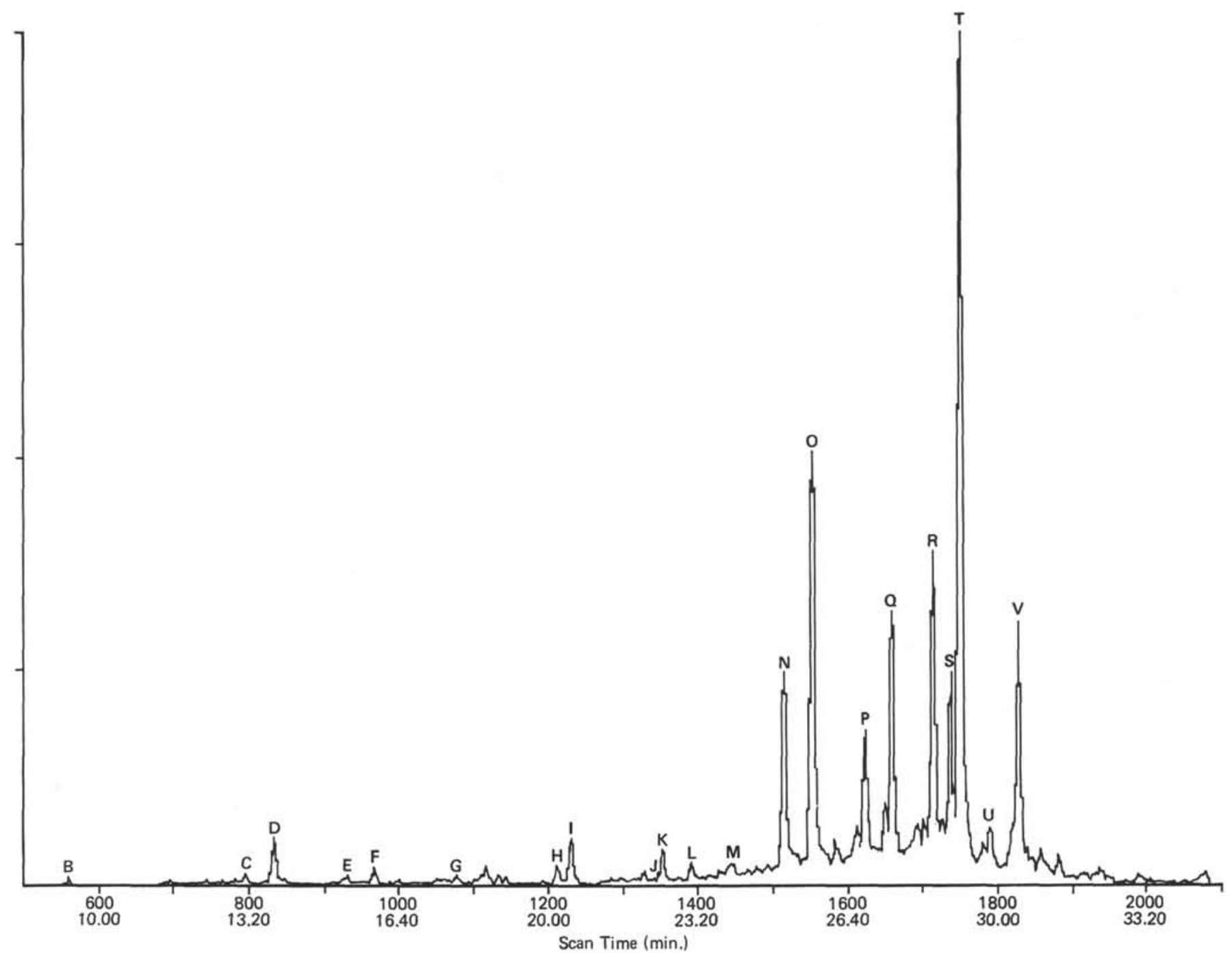

Figure 2. Mass fragmentogram of $\mathrm{m} / \mathrm{z} 217$, showing the distribution of steranes in Section 465A-38-3. (Lettered peaks refer to Table 1.)

centrations. In addition, 4,24-dimethylcholest-4-en-3one (Table 7) was speculatively identified. A complex series of components, tentatively assigned as 4-methylstenones, was detected (Table 8). The two $\mathrm{C}_{30}$ components possess almost identical mass spectra, consistent with that of 4,23,24-trimethylcholest-22-en-3-one (dinosterone; XLII). Trace amounts of 4-methylstanones were found, but the low concentrations prevented compound identification. In addition, among the numerous minor components, nuclear diunsaturated steroidal ketones were tentatively identified.

A series of hopanones $\left(\mathrm{C}_{27}-\mathrm{C}_{34}\right.$, excluding $\mathrm{C}_{28}$ and $C_{30}$ ) was detected, with one of the two $22,29,30$-trisnorhopan-21-one (XLIII) isomers greatly dominant (Table 9).

\section{Alcohols}

\section{Acyclic Components}

Only $\mathrm{C}_{12}, \mathrm{C}_{13}$, and $\mathrm{C}_{16}$ n-alkanols were recognized. No unsaturated, branched or acyclic isoprenoid alcohols (e.g., phytol) were detected.

\section{Cyclic Components}

Series $\left(\mathrm{C}_{27}-\mathrm{C}_{29}\right)$ of $\Delta^{5}$-stenols and their corresponding $5 \alpha$-stanols were identified (Table 10), with the former series dominant. In addition, 4,23,24-trimethylcholest22 -en-3 $\beta$-ol (dinosterol, LId) was recognized as a significant component of the relatively minor sterol fraction. No other $\Delta^{22}$-sterols and no 4,23,24-trimethylcholestan$3 \beta$-ol or sterols less than $C_{27}$ were detected.

\section{Carboxylic Acids}

\section{Acyclic Components}

The carboxylic acids in Section 465A-38-3 are dominated by straight-chain components ranging from $n \mathrm{C}_{10: 0}$ to $n \mathrm{C}_{27: 0}$, maximizing at $n \mathrm{C}_{16: 0}$ (Fig. 4). The higher carbon number acids $\left(n \mathrm{C}_{21}-n \mathrm{C}_{27}\right)$ were present in relatively minor amounts. A marked even-over-odd preference was apparent (CPI 8.1). Significant amounts of unsaturated carboxylic acids were found, especially $n \mathrm{C}_{16: 1}$ and $n C_{18: 1}$, (cis $\Delta^{9}$ ) as well as small relative amounts of $n \mathrm{C}_{15: 1}$ and $n \mathrm{C}_{17: 1}$. Branched components were also de- 
Table 2. Concentration of hopanes in Section 465A-38-3.

\begin{tabular}{|c|c|c|}
\hline Assignment ${ }^{\mathrm{a}}$ & Structure $^{b}$ & $\begin{array}{c}\text { Concentration } \\
(\mathrm{ng} / \mathrm{g})^{\mathrm{c}}\end{array}$ \\
\hline $18 \alpha \mathrm{H}-22,29,30$-Trisnorneohopane & VIII & 0.23 \\
\hline $17 \alpha \mathrm{H}-22,29,30$-Trisnorhopane & IXa & 2.73 \\
\hline $17 \beta \mathrm{H}-22,29,30$-Trisnorhopane & $\mathrm{Xa}$ & 5.40 \\
\hline $17 \alpha \mathrm{H}, 18 \alpha \mathrm{H}, 21 \beta \mathrm{H}-18,30$-Bisnorhopane & $\mathrm{XI}$ & 0.89 \\
\hline Bisnorhopane $\mathrm{d}^{\mathrm{d}}$ & - & 0.76 \\
\hline$\alpha \beta$-30-Norhopane & $\mathrm{IXb}$ & 2.15 \\
\hline$\beta \alpha$-30-Norhopane & $\mathrm{Xb}$ & 0.71 \\
\hline$\alpha \beta$-Hopane & IXc & 3.59 \\
\hline$\beta \beta$-30-Norhopane & XIIb & 3.26 \\
\hline$\beta \alpha$-Hopane & $\mathrm{Xc}$ & 1.32 \\
\hline $22 \mathrm{~S} \alpha \beta$-Homohopane & IXd & 0.24 \\
\hline $22 \mathrm{R} \alpha \beta$-Homohopane & IXd & 3.14 \\
\hline$\beta \beta$-Hopane & XIIc & 4.56 \\
\hline$\beta \alpha$-Homohopane & $\mathrm{Xd}$ & 1.23 \\
\hline $22 \mathrm{~S} \alpha \beta$-Bishomohopane & IXe & 0.08 \\
\hline $22 \mathrm{R} \alpha \beta$-Bishomohopane & IXe & 0.80 \\
\hline$\beta \alpha$-Bishomohopane & $\mathrm{Xe}$ & 0.26 \\
\hline$\beta \beta$-Homohopane & XIId & 13.26 \\
\hline $22 \mathrm{R} \alpha \beta$-Trishomohopane & IXf & 0.47 \\
\hline$\beta \beta$-Bishomohopane & XIIe & 3.26 \\
\hline$\beta \beta$-Trishomohopane & XIIf & 2.03 \\
\hline$\beta \beta$-Tetrakishomohopane & XIIg & 0.83 \\
\hline$\beta \beta$-Pentakishomohopane & XIIh & 1.23 \\
\hline \multicolumn{3}{|c|}{$\begin{array}{l}\text { a Based upon mass spectral interpretation, comparison with authentic } \\
\text { standards, and GC retention values. } \\
\text { b See Appendix. } \\
\text { c Dry weight of sediment. } \\
\text { d Tentative assignment based on mass spectral interpretation; stereo- } \\
\text { chemistry unknown. }\end{array}$} \\
\hline
\end{tabular}

Table 3. Concentration of sterenes in Section 465A-38-3.

\begin{tabular}{|c|c|c|}
\hline Assignment & Structure $^{\mathrm{a}}$ & $\begin{array}{l}\text { Concentration } \\
(\mathrm{ng} / \mathrm{g})^{\mathrm{b}}\end{array}$ \\
\hline $\begin{array}{l}\text { 4,23,24-Trimethyldiacholest-13(17)-ene } \mathrm{d}^{\mathrm{d}, \mathrm{e}} \\
\text { Cholest-4-ene }^{\mathrm{c}} \\
\text { Cholest-5-ene }^{\mathrm{c}} \\
\text { 24-Methylcholest-4-ene }{ }^{\mathrm{c}} \\
\text { 24-Methylcholest-5-ene } \\
\text { 23,24-Dimethylcholestadiene } \\
\text { 23,24-Dimethylcholest-22-ene } \\
\text { d, } \\
\text { 24-Ethylcholest-4-ene } \\
\text { 24-Ethylcholest-5-ene } \\
\text { 4,23,24-Trimethylcholestadiene } \\
\text { 4,f }\end{array}$ & $\begin{array}{r}\text { XIIIc } \\
\text { XIVa } \\
\text { XVa } \\
\text { XIVb } \\
\text { XVb } \\
- \\
\text { XVId } \\
\text { XIVc } \\
\text { XVc } \\
\text { XVIId }\end{array}$ & $\begin{array}{r}2.04 \\
11.05 \\
2.42 \\
4.86 \\
0.69 \\
2.36 \\
2.64 \\
10.35 \\
2.32 \\
6.84\end{array}$ \\
\hline \multicolumn{3}{|c|}{$\begin{array}{l}\text { a See Appendix. } \\
\text { b Dry weight of sediment. } \\
\text { c Based on comparison with authentic spectra and GC retention data. } \\
\text { d Based on spectral interpretation and GC retention data. } \\
\text { e May be } 24 \text {-ethyl, rather than } 23,24-\text { dimethyl. } \\
\text { f Position of the double bonds: one in } \Delta^{22} \text { position; the other unknown, } \\
\text { but nuclear. }\end{array}$} \\
\hline
\end{tabular}

tected as minor components, in particular iso- and anteiso- $\mathrm{C}_{15}$ and $\mathrm{C}_{17}$ acids. No unsaturated branched carboxylic acids were detected, but small amounts of acyclic isoprenoid acids were found.

\section{Cyclic Components}

Dehydroabietic acid (LII) and a series of hopanoid acids were detected as trace constituents. The hopanoids could not be characterized from their weak mass spectra.
Table 4. Concentration of hopenes in Section 465A-38-3.

\begin{tabular}{lcc}
\hline \multicolumn{1}{c}{ Assignment ${ }^{\mathrm{a}}$} & Structure $^{\mathrm{b}}$ & $\begin{array}{c}\text { Concentration } \\
(\mathrm{ng} / \mathrm{g})^{\mathrm{c}}\end{array}$ \\
\hline 22,29,30-Trisnorneohop-13(18)-ene & XVIII & 13.05 \\
Bisnorhopene $^{\mathrm{d}}$ & - & 1.37 \\
22,29,30-Trisnorhop-17(21)-ene & XIXa & 5.30 \\
Bisnorhopene & - & 8.74 \\
Bisnorhopene & - & 4.18 \\
30-Norhop-17(21)-ene & XIXb & 13.76 \\
Bisnorhopened & XIXc & 1.62 \\
Hop-17(21)-ene & XXI & 18.83 \\
Fern-8-ene & XX & 12.03 \\
Neohop-13(18)-ene & XXI & 0.51 \\
Fern-9(11)-ene & XIXd & 2.42 \\
22S Homohop-17(21)-ene & XXI & 0.09 \\
Fern-7-ene & XIXd & 3.56 \\
22R Homohop-17(21)-ene & XXII & 0.17 \\
Arbor-9(11)-ene & XIXe & 1.47 \\
22S Bishomohop-17(21)-ene & XIXe & 1.64 \\
22R Bishomohop-17(21)-ene & XIXf & 1.12 \\
22S Trishomohop-17(21)-ene & XIXf & 1.68 \\
22R Trishomohop-17(21)-ene & XIXg & 0.45 \\
22S Pentakishomohop-17(21)-ene & XIXg & 0.73 \\
22R Pentakishomohop-17(21)-ene & XIX & \\
\hline a Based on mass spectral interpretation, comparison with authen- \\
tic standards, and GC retention data. & \\
b See Appendix. & & \\
c Dry weight of sediment. & & \\
d Stereochemistry and structures unknown. & \\
& &
\end{tabular}

\section{Metalloporphyrins}

Nickel and vanadyl porphyrin fractions were separated by TLC and characterized by, and quantitated from their respective UV/visible absorption values (Table 11), and by mass spectrometry. The relative concentrations of metalloporphyrins with respect to the dominant component in each fraction is given in Table 12. All the vanadyl porphyrins belong to the DPEP series (LIVa), ranging from $\mathrm{C}_{27}$ to $\mathrm{C}_{32}$, with $\mathrm{C}_{31}$ dominant; they account for approximately $95 \%$ of the total metalloporphyrins. The nickel porphyrins include both DPEP (LIVb) and etio (LIII) types, with a DPEP/etio ratio of approximately unity. The nickel DPEP series ranges from $\mathrm{C}_{27}$ to $\mathrm{C}_{32}$, with $\mathrm{C}_{30}$ dominant.

Additional metalloporphyrin series were detected, but were not characterized. The major uncharacterized series eluted with the vanadyl porphyrins and ranges from $\mathrm{m} / \mathrm{z} 455$ to $\mathrm{m} / \mathrm{z} 553$ in a continuous homologous series $(455+14 n, n=0-7)$, with $\mathrm{m} / \mathrm{z} 553$ and $\mathrm{m} / \mathrm{z} 539$ dominating (Table 12). Metal-free porphyrins were not detected. However, a range of $\mathrm{C}_{30}-\mathrm{C}_{32}$ zinc DPEP porphyrins were detected as minor constituents, and the possibility that these compounds are artifacts generated from metal-free porphyrins is under investigation.

\section{DISCUSSION}

\section{Paleoenvironment: Lipid Indicators}

\section{Acyclic Components}

The distributions of straight-chain components, $n$ alkanes, $n$-alkan-2-ones, $n$-alkanoic and alkenoic acids, 
Table 5. Concentration of aromatic hydrocarbons in Section 465A-38-3.

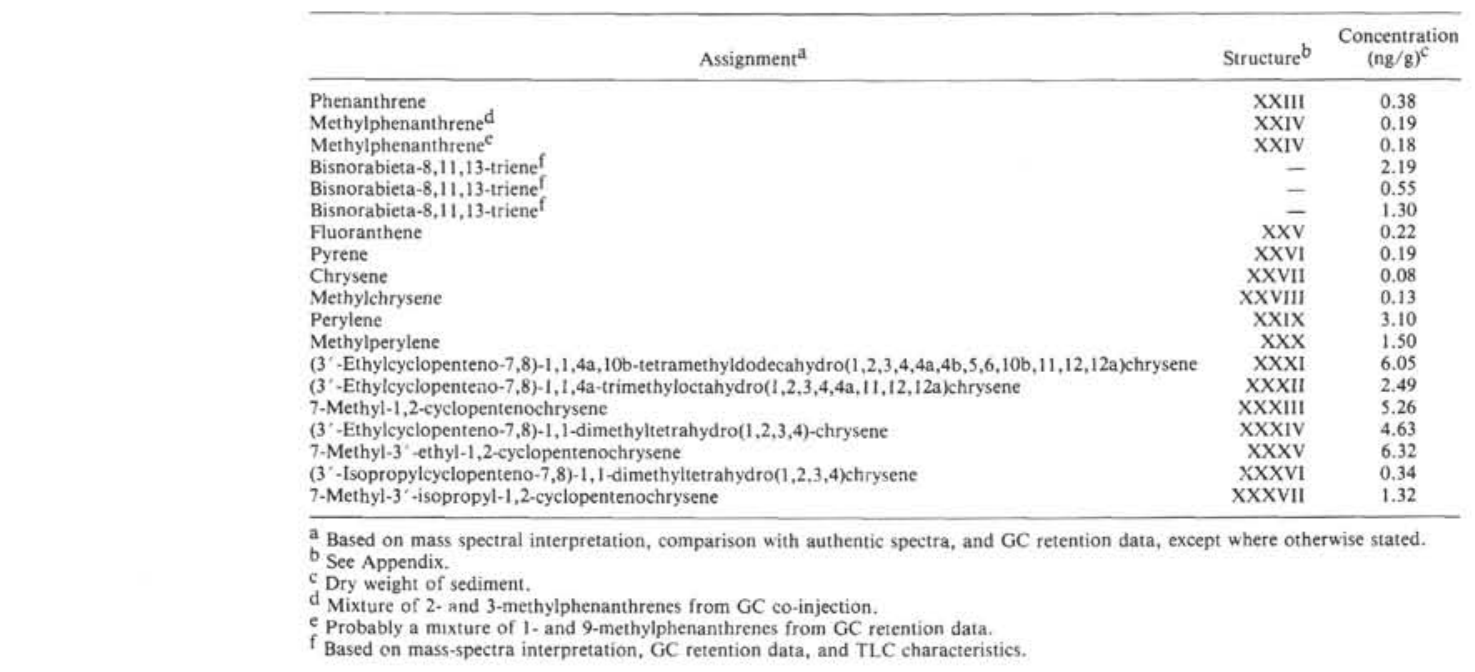

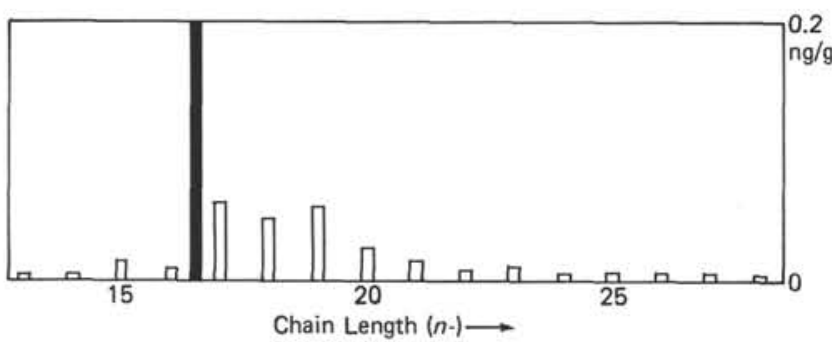

Figure 3. Distribution of acyclic ketones in Section 465A-38-3. Hollow bars $=n$-alkan-2-ones. Solid bars $=6,10,14$-trimethylpentadecan-2-one.

Table 6. Concentrations of stanones in Section 465A-38-3.

\begin{tabular}{lrc}
\hline \multicolumn{1}{c}{ Assignment ${ }^{\mathrm{a}}$} & Structure $^{\mathrm{b}}$ & $\begin{array}{r}\text { Concentration } \\
(\mathrm{ng} / \mathrm{g})^{\mathrm{c}}\end{array}$ \\
\hline 5 $\beta$-Cholestan-3-one & XXXIXa & 1.06 \\
5 $\alpha$-Cholestan-3-one & XLa & 0.70 \\
24-Methyl-5 $\beta$-cholestan-3-one & XXXIXb & 0.30 \\
24-Methyl-5 $\alpha$-cholestan-3-one & XLb & 0.36 \\
24-Ethyl-5 $\beta$-cholestan-3-one & XXXIXc & 1.03 \\
24-Ethyl-5 $\alpha$-cholestan-3-one & XLc & 1.25 \\
\hline
\end{tabular}

a Assignment based on mass spectral interpretation, comparison with literature spectra, and GC retention times.

b See Appendix.

c Dry weight of sediment.

and $n$-alkanols are consistent with inputs from marine algae (cf. Simoneit, 1978). The absence of series of longchain (i.e., $>\mathrm{C}_{21}$ ) compounds, especially $n$-alkanes with pronounced CPI values, argues against a major lipid contribution from higher-plant waxes (e.g., Eglinton and Hamilton, 1967). The monomethyl branched compounds appear as carboxylic acids; their presence is an indication of bacterial input (e.g., Cranwell, 1973).

Two major sources of the $\mathrm{C}_{18}-\mathrm{C}_{20}$ acyclic isoprenoids are possible; plant phytol and(or), for the alkanes, methanogen lipids (Holzer et al., 1979). At present, isoprenoids from these two origins cannot be distinguished, but it seems probable in view of the data given
Table 7. Concentrations of ster-4-en-3-ones in Section 465A-38-3.

\begin{tabular}{|c|c|c|}
\hline Assignment $^{\mathrm{a}}$ & Structure $^{b}$ & $\begin{array}{c}\text { Concentration } \\
(\mathrm{ng} / \mathrm{g})^{\mathrm{c}}\end{array}$ \\
\hline Cholest-4-en-3-one & XLIa & 1.5 \\
\hline 24-Methylcholest-4-en-3-one & $\mathrm{XLIb}$ & 0.3 \\
\hline 4,24-Dimethylcholest-4-en-3-one ${ }^{d}$ & - & 0.3 \\
\hline 24-Ethylcholest-4-en-3-one & XLIc & 1.1 \\
\hline
\end{tabular}

a Assignment based on mass spectral interpretation, comparison with literature spectra, and GC retention times.

b See Appendix.

c Dry weight of sediment.

d Speculative assignment based on mass spectral interpretation alone.

Table 8. Concentrations of 4-methylstenones in Section 465A-38-3.

\begin{tabular}{|c|c|c|}
\hline Assignment & Structure $^{a}$ & $\begin{array}{c}\text { Concentration } \\
(\mathrm{ng} / \mathrm{g})^{\mathrm{b}}\end{array}$ \\
\hline 4-Methylcholesten-3-one $e^{c}$ & - & 1.0 \\
\hline 4-Methylcholesten-3-one $\mathrm{c}^{\mathrm{c}}$ & - & 2.0 \\
\hline 4,24-Dimethylcholesten-3-one ${ }^{\mathrm{C}}$ & - & 0.3 \\
\hline 4,24-Dimethylcholesten-3-one $\mathrm{c}^{\mathrm{C}}$ & - & 0.3 \\
\hline 4,24-Dimethylcholesten-3-one $\mathrm{c}^{\mathrm{C}}$ & - & 0.6 \\
\hline 4,23,24-Trimethylcholest-22-en-3-one ${ }^{\mathrm{d}}$ & XLII & 0.6 \\
\hline $4,23,24$-Trimethylcholest-22-en-3-one ${ }^{\mathrm{d}}$ & XLII & 1.3 \\
\hline
\end{tabular}

a See Appendix.

$\mathrm{b}$ Dry weight of sediment.

c Speculative assignment based on mass spectral interpretation; double-bond position uncertain.

d Assignment based on mass spectral interpretation and comparison with literature spectra (Gagosian and Smith, 1979); these two isomers cannot be differentiated from their mass spectral characteristics.

below that both may be contributors in this instance. 2,6,10,15,19-pentamethyleicosane (I) and squalane (II) occur in methanogens (Holzer et al., 1979) and are probably biological markers of sediment lipid contributions from these organisms. The source of lycopane (III) is unclear; it could be formed by diagenetic hydrogenation of lycopene from algae, but a direct bacterial origin 
Table 9. Concentrations of hopanones in Section 465A-38-3.

\begin{tabular}{|c|c|c|}
\hline Assignment ${ }^{\mathrm{a}}$ & Structure $\mathrm{b}^{\mathrm{b}}$ & $\begin{array}{c}\text { Concentration } \\
(\mathrm{ng} / \mathrm{g})^{\mathrm{c}}\end{array}$ \\
\hline $22,29,30$-Trisnorhopan-21-one ${ }^{\mathrm{d}}$ & XLIII & 5.0 \\
\hline $22,29,30$-Trisnorhopan-21-one $\mathrm{d}^{\mathrm{d}}$ & XLIII & 0.4 \\
\hline 30-Norhopan-22-one ${ }^{\mathrm{d}}$ & XLIV & 0.1 \\
\hline 30-Norhopan-22-one ${ }^{\mathrm{d}}$ & XLIV & 0.1 \\
\hline Homohopan-29-one ${ }^{\text {d }}$ & XLV & 0.2 \\
\hline Homohopan-29-one ${ }^{\mathrm{d}}$ & XLV & 0.1 \\
\hline Bishomohopan-31-one & XLVI & 0.2 \\
\hline Trishomohopan-32-one & XLVII & 0.25 \\
\hline Tetrakishomohopan-33-one & XLVIII & 0.2 \\
\hline
\end{tabular}

a Based on mass spectral interpretation, comparison with literature spectra, and GC retention times.

b See Appendix.

c Dry weight of sediment.

d Stereochemistry at C-17 or C-17 and C-21 undefined.

Table 10. Concentrations of sterols ${ }^{\mathrm{a}}$ in Section 465A-38-3.

\begin{tabular}{|c|c|c|}
\hline Assignment ${ }^{\mathrm{b}}$ & Structure ${ }^{c}$ & $\begin{array}{c}\text { Concentration } \\
(\mathrm{ng} / \mathrm{g})^{\mathrm{d}}\end{array}$ \\
\hline Cholest-5-en-3 $\beta$-ol & XLIXa & 4.0 \\
\hline $5 \alpha$-Cholestan- $3 \beta$-ol & $\mathrm{La}$ & 0.4 \\
\hline 24-Methylcholest-5-en-3 $\beta$-ol & XLIXb & 0.6 \\
\hline 24-Methyl-5 $\alpha$-cholestan- $3 \beta$-ol & $\mathrm{Lb}$ & 0.4 \\
\hline 24 -Ethylcholest-5-en-3 $\beta$-ol & XLIXc & 1.0 \\
\hline 24-Ethyl- $5 \alpha$-cholestan- $3 \beta$-ol & Lc & 0.4 \\
\hline $4,23,24$-Trimethyl- $5 \alpha$-cholest-22-en- $3 \beta$-ol & LId & 1.2 \\
\hline
\end{tabular}

a Analyzed as TMS ethers.

b Based on mass spectral interpretation, comparison with literature specspectra, and GC retention times.

c See Appendix.

d Dry weight of sediment.

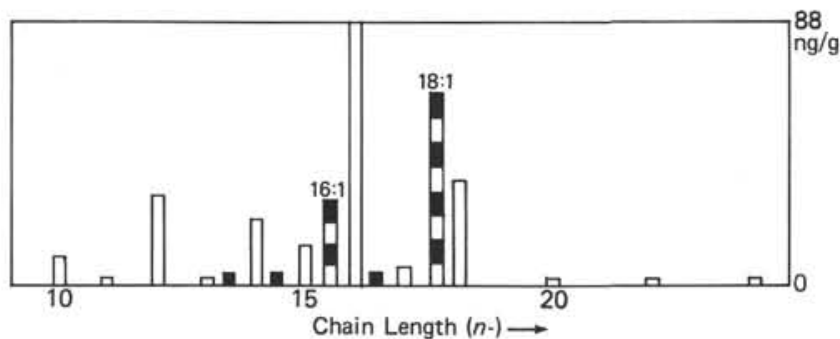

Figure 4. Distribution of acyclic carboxylic acids in Section 465A38-3. Hollow bars $=n$-alkanoic acids. Striped bars $=$ alkenoic acids (from left to right: $C_{16: 1}$ and $C_{18: 1}$ ). Solid bars $=$ branched alkanoic acids (from left to right: $\mathrm{C}_{14}, \mathrm{C}_{15}$, and $\mathrm{C}_{17}$ ).

Table 11. Metalloporphyrins in Section 465A38-3: $\mathrm{UV} /$ visible data (in $\mathrm{CH}_{2} \mathrm{Cl}_{2}$ ) and concentrations.

\begin{tabular}{lcccc}
\hline & \multicolumn{3}{c}{ Bands $(\mathrm{nm} \pm 1)$} & $\begin{array}{c}\text { Concentration } \\
\text { Species }\end{array}$ \\
& Soret & $\beta$ & $\alpha$ & $(\mu \mathrm{g} / \mathrm{g})^{\mathrm{a}}$ \\
\hline Nickel & 391 & 513 & 549 & 0.02 \\
Vanadyl & 409 & 532 & 571 & 0.62
\end{tabular}

a Pigment yield calculated using the following molar extinction coefficients $(\epsilon)$ : nickel porphyrins, $\epsilon=34820$ at $549 \mathrm{~nm}$; vanadyl porphyrins, $\epsilon=26140$ at $571 \mathrm{~nm}$.
Table 12. Relative abundances of metalloporphyrins in Section 465A38-3.

\begin{tabular}{|c|c|c|c|c|c|c|c|c|c|c|}
\hline \multicolumn{2}{|c|}{ Series (structure) } & $\mathrm{C}_{24}$ & $\mathrm{C}_{25}$ & $\mathrm{C}_{26}$ & $\mathrm{C}_{27}$ & $\mathrm{C}_{28}$ & $\mathrm{C}_{29}$ & $\mathrm{C}_{30}$ & $C_{31}$ & $\mathrm{C}_{32}$ \\
\hline \multicolumn{11}{|c|}{ Vanadyl porphyrins } \\
\hline $\begin{array}{l}\text { DPEP series } \\
\text { (LIV) }\end{array}$ & $\begin{array}{l}\text { M. } w_{i}^{a} \\
\text { R.A. }\end{array}$ & $\begin{array}{l}429 \\
-\end{array}$ & 443 & $\begin{array}{c}457 \\
-\end{array}$ & $\begin{array}{r}471 \\
2\end{array}$ & $\begin{array}{r}485 \\
9\end{array}$ & $\begin{array}{r}499 \\
23\end{array}$ & $\begin{array}{r}513 \\
60\end{array}$ & $\begin{array}{l}527 \\
100\end{array}$ & $\begin{array}{r}541 \\
44\end{array}$ \\
\hline \multicolumn{11}{|c|}{ Nickel porphyrins } \\
\hline $\begin{array}{l}\text { DPEP series } \\
\text { (LIV) } \\
\text { Etio series } \\
\text { (LIII) }\end{array}$ & $\begin{array}{l}\text { M.w.a } \\
\text { R.A.c } \\
\text { M.w. } \\
\text { R.A. }\end{array}$ & $\begin{array}{l}\frac{420}{422} \\
10\end{array}$ & $\frac{434}{436}$ & $\begin{array}{r}\frac{448}{450} \\
65\end{array}$ & $\begin{array}{r}462 \\
13 \\
464 \\
55\end{array}$ & $\begin{array}{r}476 \\
50 \\
478 \\
80\end{array}$ & $\begin{array}{r}490 \\
75 \\
492 \\
35\end{array}$ & $\begin{array}{r}504 \\
100 \\
506 \\
40\end{array}$ & $\begin{array}{r}518 \\
38 \\
520 \\
10\end{array}$ & $\begin{array}{r}532 \\
40 \\
534 \\
15\end{array}$ \\
\hline \multicolumn{11}{|c|}{ Unidentified series $^{\mathrm{d}}$} \\
\hline & $\begin{array}{l}\text { M.w }{ }^{a} \\
\text { R.A. }\end{array}$ & $\begin{array}{r}455 \\
1\end{array}$ & $\begin{array}{r}469 \\
3\end{array}$ & $\begin{array}{r}483 \\
4\end{array}$ & $\begin{array}{r}497 \\
2\end{array}$ & $\begin{array}{r}511 \\
8\end{array}$ & $\begin{array}{r}525 \\
19\end{array}$ & $\begin{array}{r}539 \\
53\end{array}$ & $\begin{array}{r}553 \\
60\end{array}$ & \\
\hline
\end{tabular}

a Molecular weight.

b Relative abundance with respect to $C_{31}$ DPEP vanadyl porphyrin.

c Relative abundance with respect to $C_{30}$ DPEP nickel porphyrin.

d The molecular weights of this series are not assigned to any particular carbon number; however, 553 is possibly a $\mathrm{C}_{33}$ homolog.

(e.g., from methanogens) is also conceivable (Brassell, Wardroper, et al., 1981).

\section{Cyclic Components}

The minor amounts of dehydroabietic acid (LII) and the aromatic diterpenoids provide evidence of a small terrigenous input from higher plants (Simoneit, 1977).

Among the steroidal components of Section 465A38-3, there are several compounds that can be attributed to marine origins, such as the dinoflagellate marker 4,23,24-trimethylcholest-22-en-3 $\beta$-ol (LId) (Boon et al., 1979). $C_{29}$ sterols have been used as indicators of terrestrial inputs (Huang and Meinschein, 1976), but without knowledge of their stereochemistry at $\mathrm{C}_{24}$ it is uncertain whether the 24-ethylcholesteroids in Section 465A-38-3 are principally derived from higher plant or algal sources. Indeed, the sterol and sterone distributions differ from that of the steranes, where 24-ethylcholestanes dominate, suggesting that there may have been contributions of $\mathrm{C}_{29}$ steroids from various sources. Certainly 23,24-dimethylcholesteroids are known only in marine organisms. The steroidal ketones also may reflect direct inputs from marine organisms; for example, sponges and dinoflagellates contain cholest-4-en-3-one (XLIa) (Delseth et al., 1979) and 4,23,24-trimethylcholest-22en-3-one (XLII) (Withers et al., 1978), respectively. Alternatively, these compounds may be diagenetic derivatives of sterols (Gaskell and Eglinton, 1975; Gagosian and Smith, 1979). The origin of the $C_{19}$ to $C_{25}$ steranes is uncertain. They may be related to the $5 \alpha$-stanols with degraded side chains previously recognized in sponges (Ballantine et al., 1977) and Neogene sediments (Brassell, Comet, Eglinton, Isaacson, et al., 1980). In addition, sponges are known to contain 24-isopropylcholesteroids (Hofheinz and Oesterhelt, 1979), which may be precursors of some $\mathrm{C}_{30}$ steranes. Two principal sources of 4-methylsteroids are possible: dinoflagellates (e.g., Withers et al., 1978, 1979) and methanotrophic bacteria (Bird et al., 1971). Although these organisms contain only 4-methylsterols and 4-methylsterones, such compounds are the probable precursors of the steroidal hydrocarbons with 4-methyl substitution. The overall distribution of 4-methylsteroids in Section 465A-38-3 is 
more suggestive of inputs from dinoflagellates than from methanotrophic bacteria. In general, the variety of the steroid side chains in Section 465A-38-3 suggests that the steroids are predominantly of marine origin (Patterson, 1971; Wardroper, 1979).

Although hopanoids occur in both eucaryotes and procaryotes, bacteria are now generally regarded as the major source of most hopanoids in the marine system (Ourisson et al., 1979). However, neohop-13(18)-ene (XX) and hop-17(21)-ene (XIXc) both may be direct lipid contributions from ferns, rather than diagenetic products of hop-22(29)-ene (Brassell, Comet, et al., $1980)$. The recognition of an extended series of $\Delta^{17(21)}$. hopenes, however, suggests that bacteria are important contributors of hopanoids to Section 465A-38-3, because procaryotes are the only type of organisms known to biosynthesize such extended compounds. Aromatic hopanoids are generally interpreted as diagenetic products of hopanoids (e.g., Ourisson et al., 1979), and therefore may also be regarded as indicators of bacterial inputs to sediments.

Until recently, ferns were the only category of biota in which fernenes (XXI) and arbor-9(11)-ene (XXII) had been recognized and these compounds were therefore regarded as biological markers of terrestrial inputs. The discovery of fernenes in a bacterium (Howard, 1980) weakens the status of these compounds as terrestrial markers. The absence of cyclic triterpenoids other than fernenes and hopanoids and of their diagenetic derivatives argues against major angiosperm inputs.

\section{Other Components}

Various origins can be proposed for the non-hopanoid aromatic hydrocarbons. It has been suggested (Wakeham et al., 1980) that phenanthrene (XXIII) and methylphenanthrenes (XXIV) may be diagenetically formed by steroid degradation. By analogy, chrysene (XXVII) and methylchrysene (XXVIII) could conceivably be derived from pentacyclic triterpenoids, although direct inputs from terrestrial sources are also possible, especially as fluoranthene (XXV) and pyrene (XXVI) cannot easily be rationalized as diagenetic products of biolipids. The origin of perylene (XXIX) and methylperylene (XXX) is uncertain (Wakeham et al., 1979, 1980).

Porphyrins are the dominant lipid components of Section $465 \mathrm{~A}-38-3$. They are geochemically derived from chlorophylls, and therefore represent molecular evidence of productivity.

In summary, the lipid composition provides qualitative evidence of contributions to the sediment from marine, terrestrial, and bacterial sources. Additionally, by grouping the lipids according to their structural affinities (Table 13), a semi-quantitative indication of these inputs, which may serve as a paleoenvironmental signature (Fig. 5), emerges. The immediate problem arising from this approach is that numerous unrecognized or unknown compounds cannot be included in such a classification. However, the majority of such lipids are only minor components of the sample, so their absence should not significantly affect the outcome. A further problem is that the lipid composition has not remained static since deposition, but has changed in response to diagenesis. The extent of the influence of diagenetic processes on the distribution of lipid structural types is uncertain. In general, however, the products of known diagenetic transformations can be related to their precursors, and therefore may be accounted for. It seems improbable that a significant proportion of lipids will lose their structural identity until the advent of catagenesis.

The dominance of lipids of marine algal origin in Section $465 \mathrm{~A}-38-3$ is clearly illustrated in the distribution of lipid structural types (Fig. 5; Table 13). Bacterial inputs, especially hopanoids, are also prominent, but lipids of terrestrial origin are only minor constituents. Such lipid data are consistent with those from visual examination of the kerogen; both show that the organic matter in the sample is principally derived from marine sources, possibly reflecting high algal productivity.

In addition to the overall structural grouping of lipids, the steroids can be subdivided according to their side chains and C-4 substitution (Table 14; Fig. 6). As a result of the taxonomic specificity of sterol biosynthesis, the occurrence of particular side chains appears restricted to specific classes of organisms (Patterson, 1971). Hence, several of the steroidal subdivisions of Table 14 reflect inputs from marine biota. Indeed, this classification represents a marked improvement on the simplistic approach of Huang and Meinschein (1979), although further improvements, especially the inclusion of data for steroidal $\mathrm{C}_{24}$ stereochemistry, are envisaged.

\section{Paleoenvironment: Comparison of Section 465A-38-3 with Other Cretaceous DSDP Samples}

The results from the Leg 62 Albian sample (when expressed as structural ratios) show major differences and some similarities with three other previously described Cretaceous samples of deep-sea origin (Table 15).

It must be stressed that each of these Cretaceous samples is of a different degree of maturity. Hence, the detailed composition in terms of individual compounds and of functionalized lipids as chemical classes (alcohols, carboxylic acids, ketones, etc.) varies greatly with maturity from sample to sample. However, by using structural summation, the effects of diagenesis are minimized, although not eliminated, and intersample lipid comparison becomes more acceptable; nevertheless, this approach will require further extensive study to evaluate the effect of increasing diagenesis (maturation) on the structural ratios. For example, the Leg 61 samples which are of high maturity showed relative enhancement of the $n$-alkanes, presumably as a consequence of their preferential catagenetic release from the kerogen with proximity to the oil-generation zone.

The most significant difference between Leg 62 and the lipids from previously described DSDP Legs is that the relative and absolute porphyrin content of the Leg 62 sample is much higher than in any Cretaceous sample previously described by us; this is rationalized in terms of a higher productivity environment for the vicinity of 
Table 13. Quantitative distribution (ng/g) of gross structural types according to functionality, Section 465A-38-3.

\begin{tabular}{|c|c|c|c|c|c|c|c|c|c|}
\hline \multirow{2}{*}{$\begin{array}{l}\text { No. in } \\
\text { Figure } 5\end{array}$} & \multirow[b]{2}{*}{ Structural Type } & \multicolumn{6}{|c|}{ Functional Group } & \multirow[b]{2}{*}{ Total } & \multirow[b]{2}{*}{ Comment } \\
\hline & & Acids $^{\mathrm{a}}$ & Alcohols ${ }^{b}$ & Ketones ${ }^{c}$ & Alkanes & Alkenes $\mathrm{d}, \mathrm{e}$ & Aromatics ${ }^{\mathrm{e}}$ & & \\
\hline 1 & Short chain $\left(n \mathrm{C}_{10}-\mathrm{C}_{20}\right)$ & 263 & 1.2 & 0.8 & 48.9 & - & - & 313.9 & Algal \\
\hline 3 & $\begin{array}{l}\text { Monomethyl branched straight } \\
\text { chain }\left(n \mathrm{C}_{10}-\mathrm{C}_{20}\right)\end{array}$ & 10.0 & - & - & - & - & - & 10.0 & Bacterial \\
\hline 4 & $\begin{array}{l}\text { Acyclic diterpenoid } \\
\text { (pristane, phytane, etc.) }\end{array}$ & 0.5 & - & 0.2 & 6.2 & - & - & 6.9 & Algal or bacterial \\
\hline 6 & $\begin{array}{l}\text { Acyclic triterpenoid } \\
\text { (squalane) }\end{array}$ & - & - & - & 1.0 & - & - & 1.0 & Bacterial \\
\hline 7 & $\begin{array}{l}\text { Acyclic tetraterpenoid } \\
\text { (lycopane) }\end{array}$ & - & - & - & 17.9 & - & - & 17.9 & ?Marine algal or bacterial \\
\hline 8 & Cyclic diterpenoid & 1.0 & - & - & - & - & 4.0 & 5.0 & Terrestrial \\
\hline 9 & Hopanoid & 1.0 & - & 6.2 & 52.4 & 92.3 & 26.4 & 178.4 & Bacterial \\
\hline 10 & Non-hopanoid triterpenoid & - & - & - & - & 2.8 & - & 2.8 & Mixed marine \\
\hline
\end{tabular}

Note: $-=$ not detected.

a Includes alkanoic and alkenoic acids; concentrations are quoted as mole fractions of the appropriate saturated hydrocarbon.

$\mathrm{b}$ Includes alkanols and alkenols (e.g., $\Delta^{5}$-stenols and $\Delta^{22}$-stanols); concentrations are quoted as mole fractions of the appropriate saturated hydrocarbon.

c Includes alkanones (e.g., stanones) and alkenones (e.g., ster-4-en-3-ones); concentrations are quoted as mole fractions of the appropriate saturated hydrocarbon.

d All compounds are monounsaturated.

e Concentrations of compounds quoted directly, not as mole fractions of saturated hydrocarbon, because of limits of experimental error.

the Hess Rise during the Albian. Similarly, the considerable abundance of short straight-chain material and minor amounts of long straight-chain material show that algal components appear to be greatly dominant over terrestrial. This is interpreted as indicating that the Hess Rise area during the Albian was under facies control different from that at the other described Cretaceous sites.

From the comparison of the relative abundances of lipid structural types (Table 15), Section 465A-38-3 most closely resembles the Leg 48 Albian limestone. Hence, the lipids appear to reflect the similarity of age and lithology of these samples, although this similarity is not always apparent from the individual lipid distributions; for example, sterenes dominate Section 465A-38-3, whereas diasterenes are the major steroids of Section 402A-18-1.

Visual kerogen results corroborate the lipid data. The organic matter consists mainly of sapropelic structureless "kerogen" of presumed marine algal origin; this predominantly autochthonous material contains a few vitrinite particles and some spores as a minor terrestrial contribution.

\section{Diagenesis}

\section{General Appraisal}

The detailed study of a single sample from a DSDP hole inevitably does not permit an evaluation of the major diagenetic trends at that site. However, the lipids of Section 465A-38-3 can be related to stages of known diagenetic pathways, thereby enabling an assessment of the maturity status of this sample.
Sample immaturity is shown by the presence of functional lipids, namely alkenes, ketones, alcohols, and carboxylic acids that do not survive extensive diagenesis. In particular, such a well-preserved Cretaceous assemblage of labile lipids suggests that post-depositional microbial activity has not drastically affected the lipid distribution. Furthermore, the sample has not experienced much thermal stress.

\section{Acyclic Components}

In general, acyclic lipids are less valuable indicators of sediment maturity than cyclic components, and the composition of Section 465A-38-3 reflects this fact. Low CPI values for $n$-alkanes typify both mature sediments and immature samples where these compounds are principally derived from algal and bacterial sources (e.g., Simoneit, 1978). The high CPI value for the $n$-alkanoic acids and the presence of alkenoic acids strongly suggest sediment immaturity. A similarity between $n$-alkan-2-one and $n$-alkane distributions may reflect their common biological origin, or indicate that alkane oxidation has occurred prior to deposition (Brassell, Comet, et al., 1980). For Section 465A-38-3, these two possibilities cannot be distinguished.

Most of the acyclic isoprenoid alkanes found in Section 465A-38-3 occur over a wide range of maturity, from recently deposited sediments to crude oils. The exceptions, lycopane (III) and 2,6,10,15,19-pentamethyleicosane (I), are less well-documented bio- and geolipids, although their presence is probably not significant as a diagenetic indicator. The stereochemistry of these acyclic isoprenoid alkanes, however, would denote their thermal maturity (cf., Patience et al., 1978). Since 6,10, 


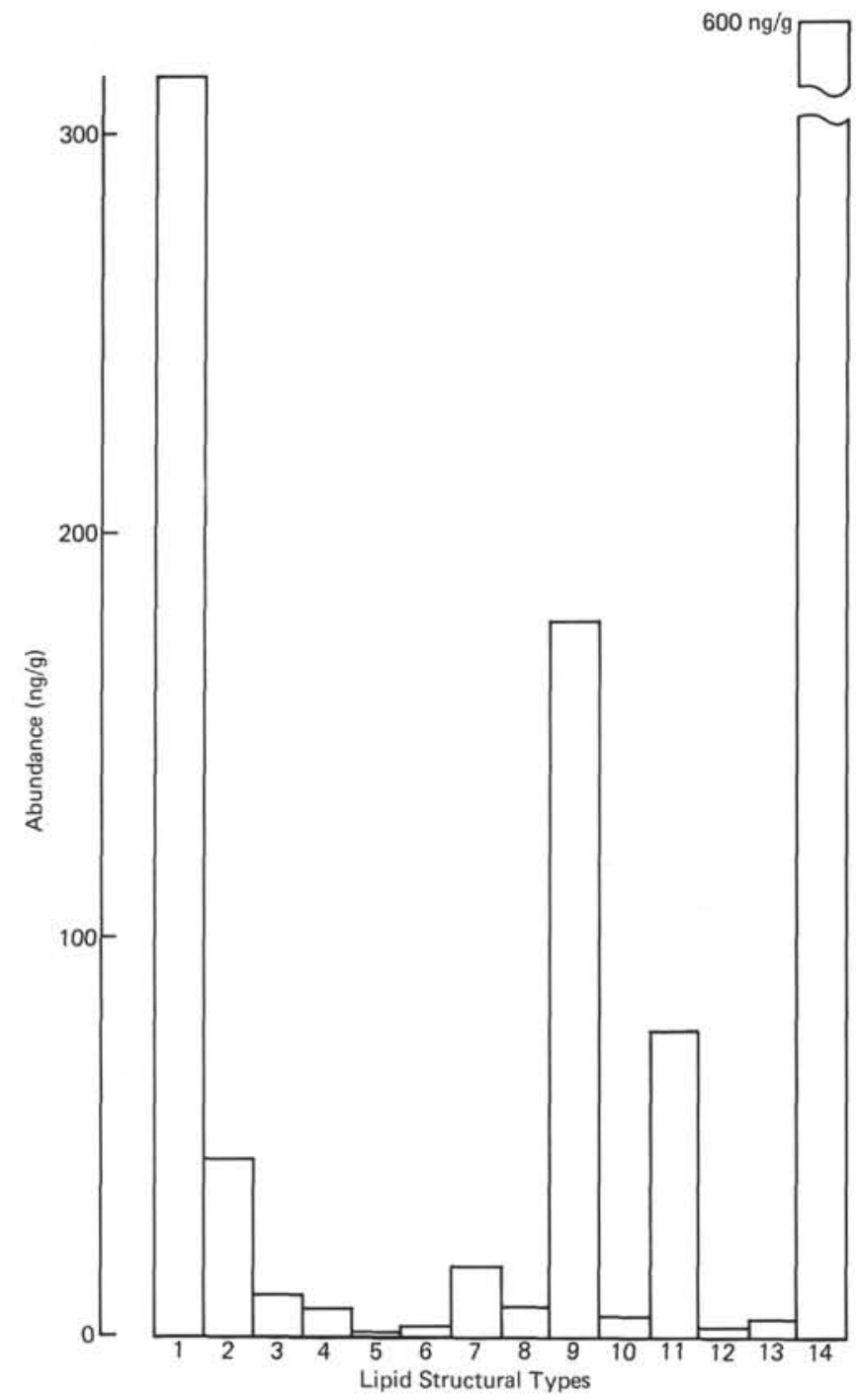

Figure 5. Distribution of lipid structural types in Section 465A-38-3 (cf., Table 13) 14-trimethylpentadecan-2-one (XXXVIII) is not known in mature sediments, its presence in Section 465A-38-3 indicates sample immaturity.

\section{Cyclic Components}

The minor amounts of diterpenoids in Section 465A38-3 provide little evidence of diagenetic trends or sample maturity. In contrast, the steroidal constituents reflect various diagenetic processes. First, the stenones and stanones may be intermediates in the diagenetic conversion of stenols to stanols (Gaskell and Eglinton, 1975; Gagosian and Smith, 1979), although, as stated above, a direct input of steroidal ketones from organisms is possible. Indeed, steroidal ketones have not been widely reported as constituents of ancient sediments, and their role in steroidal diagenetic transformations is unclear. It may be significant, however, that the distributions of $\mathrm{C}_{27}$ to $\mathrm{C}_{29} \Delta^{5}$-stenols, $5 \alpha$-stanols, $5 \alpha$ - and $5 \beta$-stan-3-ones and ster-4-en-ones are generally similar, suggesting a diagenetic or source related relationship between them. The distributions of sterenes and steranes also resemble that of the oxygenated steroids, except that carbon number ranges of the sterenes and steranes are greater. The absence of sterols or sterones with degraded side chains (i.e., $\mathrm{C}_{19}-\mathrm{C}_{26}$ components) makes it uncertain whether their sterane counterparts are formed by steroidal degradation, or are diagenetically derived from precursors with similar carbon skeletons.

$\Delta^{4}$-sterenes are the dominant steroidal alkenes, and $\Delta^{5}$-sterenes are also abundant. $\Delta^{2}$-sterenes are important intermediates in the formation of $\Delta^{4}$ - and $\Delta^{5}$-sterenes, diasterenes, steranes, and diasteranes from stanols (e.g., Dastillung and Albrecht, 1977). The absence of $\Delta^{2}$ sterenes here and the abundance of $\Delta^{4}$ - and $\Delta^{5}$-sterenes provides an estimate of the maturity of the sediment. $\Delta^{2}$-sterenes usually dominate the sterenes of young sediments, whereas older sediments tend to have $\Delta^{4}$ and $\Delta^{5}$-sterenes in greater abundance than $\Delta^{2}$-sterenes (Wardroper, 1979). In Section 465A-38-3, $\Delta^{2}$-sterenes were not detected, yet their presumed precursors

Table 14. Quantitative distribution (ng/g) of steroidal structures according to functionality, Section 465A-38-3.

\begin{tabular}{|c|c|c|c|c|c|c|c|}
\hline \multirow{2}{*}{$\begin{array}{l}\text { No. in } \\
\text { Figure } 6\end{array}$} & \multirow[b]{2}{*}{ Hydrocarbon Skeleton } & \multicolumn{4}{|c|}{ Functional Group } & \multirow[b]{2}{*}{ Total } & \multirow[b]{2}{*}{ Comment } \\
\hline & & Alcohols $^{\mathrm{a}}$ & Ketones $^{b}$ & Alkanes & Alkenes ${ }^{c, d}$ & & \\
\hline \multirow{6}{*}{1} & Androstane & - & - & 0.4 & - & 0.4 & Marine \\
\hline & Pregnane & - & - & 0.3 & - & 0.3 & Marine \\
\hline & 20-Methylpregnane & - & - & 0.1 & - & 0.1 & Marine \\
\hline & 20-Ethylpregnane & - & - & 0.03 & - & 0.1 & Marine \\
\hline & Cholane & - & - & 0.3 & - & 0.3 & Marine \\
\hline & 24-Methylcholane & - & - & 0.06 & - & 0.1 & Marine \\
\hline 2 & Cholestane & 3.3 & 3.2 & 3.2 & 13.5 & 23.1 & Mixed \\
\hline 3 & 24-Methylcholestane & 0.8 & 1.0 & 1.6 & 5.6 & 8.9 & Mixed \\
\hline 4 & 23,24-Dimethylcholestane & - & - & 0.7 & 5.0 & 5.7 & Marine \\
\hline 5 & 24-Ethylcholestane & 1.1 & 3.3 & 5.1 & 12.7 & 22.1 & Terrestrial? \\
\hline 6 & 24-Propylcholestane & - & - & 1.4 & - & 1.4 & Marine \\
\hline 7 & 4-Methylpregnane & - & - & 0.1 & - & 0.1 & Marine algal \\
\hline 8 & 4-Methyl-24-norcholestane & - & - & 0.2 & - & 0.2 & Marine algal \\
\hline 9 & 4-Methylcholestane & - & 3.2 & - & - & 3.2 & Marine algal \\
\hline 10 & 4,24-Dimethylcholestane & - & 1.1 & - & - & 1.1 & Marine algal \\
\hline 11 & 4,23,24-Trimethylcholestane & 0.8 & 1.8 & - & 8.8 & 11.4 & Marine algal \\
\hline \multicolumn{8}{|c|}{$\begin{array}{l}\text { Note: }-=\text { not detected. } \\
\text { a Includes alkanols (e.8., stanols) and alkenols (e.g., } \Delta 5 \text {-stenols and } \Delta^{22} \text {-stanols); concentrations are quoted as mole } \\
\text { fractions of the appropriate saturated hydrocarbon skelefon. } \\
\text { b Includes alkenones (e.g., ster-4-en-3-ones) and alkanones (e.g., stanones); concentrations are quoted as mole frac- } \\
\text { tions of the appropriate saturated hydrocarbon skeleton. } \\
\text { e Concentrations of compounds are not recalculated as mole fractions of saturated hydrocarbon, because of the } \\
\text { d limits of experimental error. } \\
\text { terizationes and aromatic steroids present only in trace amounts are not included, because of incomplete charac- }\end{array}$} \\
\hline
\end{tabular}




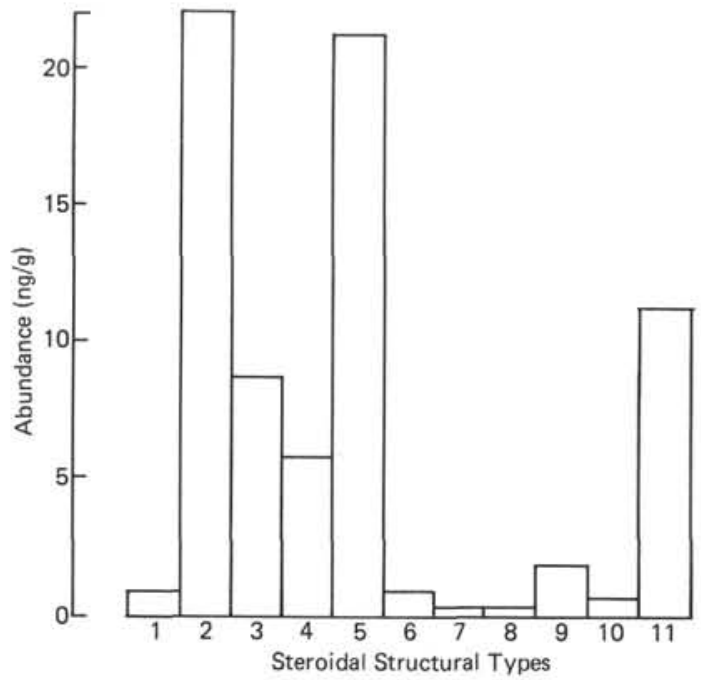

Figure 6. Distribution of steroidal structural types in Section 465A38-3 (cf., Table 14).

(stanols) and various diagenetic products were found. A similar distribution of steroidal components were found in sediments from the deeper parts of Site 440 (Brassell, 1980). It appears either that the transformation of stanol to $\Delta^{2}$-sterene occurs only within a particular early stage of diagenesis, or that at later stages any $\Delta^{2}$ sterenes formed from stanols are rapidly converted into their $\Delta^{4}$ - and $\Delta^{5}$-analogs. These data show that the published diagenetic processes of steroidal diagenesis (e.g., Dastillung and Albrecht, 1977) are simplistic approximations. The high carbonate and low clay content of the sediment and the alkaline conditions (site reports, this volume) may have affected the steroidal distributions. Perhaps the non-acidity of the sediment results in a low rate of hydrogenation; this may explain the presence of stenones.

The presence of a single diasterene (XIIIc), rather than a series of diasterenes, is curious. The distributions of diasterenes and diasteranes in Section 465A-38-3 dif- fer markedly from those of the stanols or sterenes, apparently precluding a direct diagenetic relationship between them. The generally minor amounts of diasteroids recognized possibly reflect the low clay content of Section 465A-38-3, since the diasterene formation is catalyzed by acidic clay (Rubinstein et al., 1975). It may also be significant that this diasterene (XIIIc) possesses 4-methyl substitution; perhaps such substitution aids or stabilizes the backbone rearrangement process. Indeed, the 4,23,24-trimethylcholestadiene and 4-methyldiasterene found may be products of direct dehydration and rearrangement of dinosterol $[4,23,24$-trimethyl- $5 \alpha$-cholest-22-en-3 $\beta$-ol (LId)], respectively. If so, it would appear that the proclivity of steroidal diagenetic processes may be dependent on the precursor sterol (i.e., whether it possesses 4-methyl substitution, $\Delta^{7}$ unsaturation, etc.).

In general, the distribution of steroidal components of Section 465A-38-3 attests the immaturity of the sediment, as is also shown by the sterane stereochemistry (only $5 \alpha$ - and $5 \beta$-isomers of $20 \mathrm{R}-8 \alpha, 14 \alpha, 17 \alpha$-steranes are present; cf. Mackenzie et al., 1980). In an attempt to describe the steroid maturity of Section 465A-38-3 in semi-quantitative terms, the relative concentrations of the cholesteroids can be plotted (Fig. 7).

Similar treatment of other DSDP samples may help establish a reference framework for accurate assessment of the diagenetic state of immature sediments. For Section 465A-38-3, cholesterenes dominate, with $\mathrm{C}_{27}$ sterols, sterones, and steranes all present in significant amounts. In less mature samples, the sterols and sterones can be expected to dominate; in more mature sediments, the steranes will predominate. The sensitivity and utility of this approach to diagenetic assessment needs investigation.

The distribution of hopanoids is consistent with sample immaturity; $\beta \beta$-hopanes dominate their $\alpha \beta$ and $\beta \alpha$ isomers, and hopanoid alkenes, alkanones, and alkanoic acids are all present (Table 13). Few of the hopanoids recognized represent direct biological inputs; in the main, they are believed to be diagenetic products, many of which are formed from polyhydroxybacterio-

Table 15. Comparison of relative abundances of lipid structural types in DSDP Cretaceous sediments.

\begin{tabular}{|c|c|c|c|c|}
\hline Molecular Structural Types & $\begin{array}{c}\text { 465A-38-3; } \\
\text { Hess Rise, N.W. } \\
\text { Pacific; } \\
\text { Organic-Rich } \\
\text { Limestone; } \\
\text { U. Albian }\end{array}$ & $\begin{array}{c}\text { 462-54-2; } \\
\text { Nauru Basin, N.W. } \\
\text { Pacific: } \\
\text { Organic-Poor } \\
\text { Limestone; } \\
\text { Campanian }\end{array}$ & $\begin{array}{l}\text { 416A-14-4; } \\
\text { Moroccan Basin, } \\
\text { N.E. Atlantic; } \\
\text { Argillaceous } \\
\text { Turbidite; } \\
\text { Valanginian }\end{array}$ & $\begin{array}{c}\text { 402A-18-1; } \\
\text { Bay of Biscay, } \\
\text { N.E. Atlantic; } \\
\text { Laminated Organic- } \\
\text { Rich Limestone: } \\
\text { Albian }\end{array}$ \\
\hline Short chain $\left(n \mathrm{C}_{10-20}\right)$ & +++ & tr & +++ & ++ \\
\hline Long chain $\left(n \mathrm{C}_{21-35}\right)$ & ++ & ++++ & ++++ & ++ \\
\hline Mono-methyl branched (straight-chain) & + & - & tr & tr \\
\hline Acyclic diterpenoid & ++ & - & ++ & ++ \\
\hline Acyclic sesterterpenoid & + & - & + & N.E. \\
\hline Acyclic triterpenoid & + & - & + & N.E. \\
\hline Acyclic tetraterpenoid & ++ & - & - & - \\
\hline Cyclic diterpenoid & + & - & tr & tr \\
\hline Hopanoid & +++ & ++++ & +++ & ++++ \\
\hline Non-hopanoid triterpenoid & + & - & - & - \\
\hline Steroid & ++ & +++ & ++ & ++ \\
\hline 4-Me steroid & ++ & - & ++ & + \\
\hline PNA (non-biogenic) & + & - & + & + \\
\hline Porphyrin & ++++ & - & ++ & ++ \\
\hline
\end{tabular}

Notes: Symbols employed for expressing semi-quantitative abundances (as $\%$ of the total) for the lipid fraction: $+++++=$ $50-100 \% ;++++=25-50 \% ;+++=10-25 \% ;++=1-10 \% ;+=0.1-1 \% ; \mathrm{tr}=\langle 0.1 \% ;-=$ not detected; N.E. $=$ not examined. Sources for data reported: Barnes et al., 1979; Wardroper, 1979 (Leg 48); Brassell, Comet, Eglinton, McEvoy, early legs, particularly Leg 48 , are more qualitative than quantitative, owing to the procedures employed. 


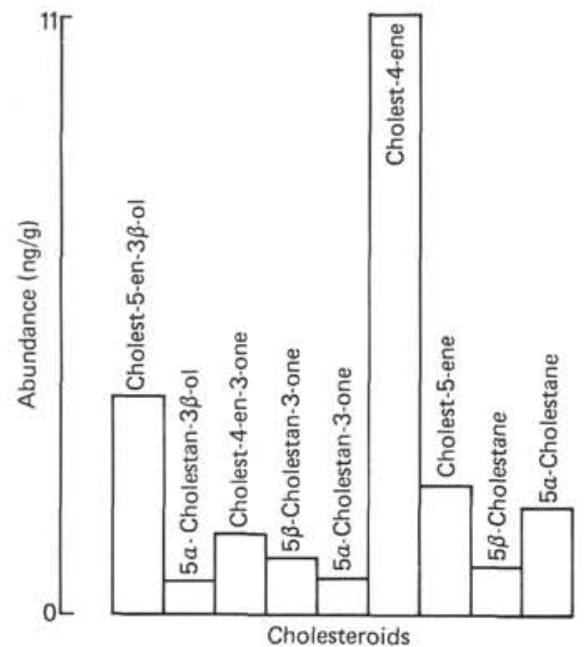

Figure 7. Distribution of cholesteroids in Section 465A-38-3.

hopanes. For examples, hopanoid acids and hopanones, other than $\beta \beta$-29-norhopan-22-one (e.g., Berti et al., 1963), have not been found in organisms, but both series of components probably arise from the polyhydroxybacteriohopanes (e.g., Wardroper, 1979). Certainly, the lack of similarity in the distributions of hopanones and hopanes shows that the former are not oxidation products from the latter. As discussed above, hop-17(21)-ene (XIX) and neohop-13(18)-ene (XX) may both originate from the direct input of ferns (Berti and Bottari, 1968), or from diagenetic isomerization of hop22(29)-ene via hop-21-ene (Ensminger, 1977).

For Section 465A-38-3, these two origins cannot be distinguished. The presence of an extended series of $\Delta^{17(21)}$-hopenes, however, supports the argument for diagenetic formation of the $\mathrm{C}_{30}$ hopenes; also, no traces of their precursors were detected. This situation parallels that found towards the bottom of Site 440 (Brassell, Comet, et al., 1980), and also at Sites 416 (Moroccan Basin; Brassell, Comet, Eglinton, McEvoy, et al., 1980) and 402 (Bay of Biscay; Barnes et al., 1979), suggesting that it may be typical of immature deep-sea sediments. In addition, $\beta \beta$-hopanes dominate their $\beta \alpha$ - and $\alpha \beta$ isomers, as they do in other immature Cretaceous deepsea sediments. A further measure of sediment maturity is provided by the ratio of $22 \mathrm{~S}$ and $22 \mathrm{R}$ diastereoisomers of $\alpha \beta$-hopanes, which increases with increasing maturity (e.g., Ensminger, 1977; Mackenzie et al., 1980). In Section 465A-38-3, as in other Cretaceous samples (e.g., Barnes et al., 1979), the $22 \mathrm{R}$ isomers are greatly dominant $(22 R / 22 S=13.8)$, indicating the immaturity of the sample, in contrast to Leg 61 samples (Thomson et al., in press), where only $\alpha \beta$-hopanes with $22 \mathrm{~S}$ isomers dominant were detected. For the extended series of $\Delta^{17(21)}$-hopenes, the ratio of $22 \mathrm{R}$ to $22 \mathrm{~S}$ isomers is markedly closer to unity $(\mathrm{R} / \mathrm{S}=1.4)$ than for the $\alpha \beta$-hopanes. This suggests that $C_{22}$ epimerization occurs faster in hopenes than in hopanes.

The presence of partially to fully aromatized hopanoids in Section 465A-38-3 is consistent with the postulated diagenetic sequence of successive aromatization from ring D through rings C, B, and A (Greiner et al.,
1976, 1977; Spyckerelle et al., 1977a, b). These compounds are early-stage diagenetic products occurring in immature sediments of Recent (Tissier and Spyckerelle, 1977; Tissier and Dastillung, 1978) through Cretaceous age (Barnes et al., 1979; Brassell, Comet, Eglinton, McEvoy, et al., 1980). The significance of the aromatic hopanoids without side chains and with ethyl and isopropyl side chains is unclear.

The diagenetic transformations of fernenes are poorly understood. It has been postulated from data for Site 440 in the Japan Trench (Brassell, 1980) that fern-7-ene and fern-9(11)-ene may isomerize to fern-8-ene (XXI). In Section 465A-38-3, the dominance of fern-8-ene over its $\Delta^{7}$ and $\Delta^{9(11)}$ isomers is greater than that towards the bottom of Site 440 , probably reflecting the greater maturity of the Leg 62 sample.

\section{Metalloporphyrins}

Metalloporphyrins are the major class of lipid detected. Nickel porphyrins of both DPEP (deoxophylloerythroetioporphyrin) and etio types were present in approximately equal amounts. In contrast, vanadyl porphyrins comprise $95 \%$ of the total metalloporphyrins, yet they consist entirely of DPEP components. The absence of free base porphyrins indicates that chlorin diagenesis is complete. The defunctionalization of chlorophyll $a$ would formally produce a $\mathrm{C}_{32}$ porphyrin (Treibs, 1936; Maxwell et al., in press), whereas in Section 465A38-3 vanadyl $C_{31}$ DPEP is predominant and the nickel porphyrins are dominated by $\mathrm{C}_{30}$ DPEP and $\mathrm{C}_{28}$ etioporphyrins. Such dealkylation is thought to be caused by high thermal stress, or possibly by an oxidative degradation of chlorophyll (Baker, Palmer, Huang, et al., 1978). In the present instance, we favor the latter possibility, as the alkaline nature of the sedimentary interstitial water (site report, this volume) suggests that conditions for oxidative degradation may have existed. In addition, the absence of vanadyl etioporphyrins and of extended porphyrins (i.e., $>\mathrm{C}_{32}$ ) indicates a mild thermal history (Baker et al., 1978; Maxwell et al., in press). The dominance of vanadyl complexes over nickel complexes may be accounted for, in part, by their greater thermodynamic stability (Palmer et al., 1979). However, comparison with metalloporphyrin data for Cretaceous sediments from the Moroccan Basin (Leg 50; Brassell, Comet, Eglinton, McEvoy, et al., 1980; Palmer and Baker, 1980) reveals an anomaly. The total lipid distributions for Leg 50 were diagenetically more mature than Section 465A-38-3, yet only nickel porphyrins, comprising both DPEP and etioporphyrin series, were detected in Leg 50 material. These differences may reflect different source materials and(or) different inorganic sedimentary conditions, i.e., low clay and high carbonate contents and alkaline interstitial water for Leg 62, compared with the high clay content and acidic sedimentary environment for the Leg 50 turbidites.

\section{CONCLUSIONS}

\section{General}

The lipid composition of Section 465A-38-3 is dominated by components derived from marine algae, sug- 
gesting a high productivity environment. The relative and absolute abundances of porphyrins and short straight-chain components attest this suggestion, which is also supported by the presence of specific marine markers such as dinosterol. Lipids that can be assigned to terrestrial origins are present in low amounts. They include diterpenoids and triterpenoids derived from conifer resins and ferns. No biological markers or lipid distributions characteristic of angiosperms were observed. In addition, the aromatic hydrocarbons not directly related to biogenic precursors (principally derived from terrestrial sources) were present in low amounts. Evidence of major bacterial contributions to the sediment is provided by abundant hopanoids. The branched components and acyclic isoprenoid alkanes, which are probably derived from various sulphate reducers and methanogens, are present in minor concentration.

The maturity of Section 465A-38-3 is comparable to that of other Cretaceous DSDP samples-greater than that of Neogene sediments from the Japan Trench, and less than that of Cretaceous Nauru Basin sediments. Its overall immaturity, as shown by the lipid data, is consistent with the low vitrinite reflectance of the sample.

\section{Paleoenvironmental Interpretation}

A predominantly algal assemblage in a Lower Cretaceous "black shale" is unusual; most "black shales" appear to be of terrestrial, bacterial, or mixed origins (Barnes et al., 1979; Tissot et al., 1980). The finding of a well preserved assemblage of highly biodegradable lipids such as alkenoic and alkanoic acids and low molecular weight alkanes, all of algal origin, implies that the post-depositional microbial activity may not have drastically altered the original lipid distribution pattern. However, the high relative hopane concentration implies that microbial activity was nevertheless considerable.

An extensive microbial population may have utilized the small amounts of oxygen in the water column and the more easily degradable organic material in the sediment, such as carbohydrates and amino acids, which were consumed preferentially, leaving a relatively undegraded lipid "resistate" fraction. The lipids were not degraded extensively, because of (1) the low levels of available oxygen and (2) their rapid burial in the sediment.

Three environmental situations may be proposed to explain this non-degraded assemblage of algal lipids in which hopane producers (probably mainly bacteria) still played a significant role:

1) The bottom waters were stagnant and overlain by a highly productive water mass. In stagnant basins, hydrogen sulfide is often present in the water column (e.g., Cariaco Trench).

2) The environment was oxygen-depleted, but not poisoned with $\mathrm{H}_{2} \mathrm{~S}$. Residual oxygen was present in the lower levels of the water column. This environment can occur in some contemporary upwellings as oxygen minima. Bacterial activity is often very extensive in such environments (e.g., Walvis Bay).
3) The environment was characterized by high sediment-accumulation rates associated with high productivity. Lipid preservation resulted from rapid burial.

It is not easy to choose between these three models. From the available data (site reports, this volume), the upper Albian of Site 465 was deposited during a period of high sedimentation, thus favoring the third model. Further evidence for this model is implied by the platetectonic reconstructions of Lancelot and Larson (1975). Their reconstruction places the Hess Rise during the Early Cretaceous within the equatorial high productivity area. The work of Shackleton and Boersma (site reports, this volume) shows that warm water and high fertility accompanied deposition in the South Atlantic, and that this may have affected the Pacific as well during the Albian. The present lipid data strongly support the idea of a major autochthonous contribution, with a minor allochthonous component, high productivity being chiefly responsible for the lipid distributions. In support of this idea, the results at Sites 463 and 464 show that lower sedimentation rates occurred during the late $\mathrm{Al}$ bian, and the organic carbon contents here are notably lower. It would therefore appear that a relationship exists between high productivity, sedimentation rate, and type and amount of organic matter. However, at Site 463 the high productivity during the Late Cretaceous has not resulted in enhanced organic carbon values, although it did produce a greater thickness of biogenic pelagic deposit, which tends to negate the idea of a direct relationship between sedimentation rate and organic carbon. An additional phenomenon must therefore be invoked to account for the enhanced organic carbon values in the Lower Cretaceous of the Hess Rise. We believe that this is some regional effect in which the levels of oxygen within the water column were sufficient to ensure oxidation of a low flux of slowly deposited organic matter, i.e., an oxygen minimum, but insufficient to oxidize the enhanced organic carbon input of a highly productive water column. The final product was the deposition of organic-rich oozes of algal derivation with a strong bacteria "overprint." Other evidence of oxygen deficiency during sedimentation in the Albian is provided by the extensive sequences with fine-scale sedimentary lamination (site reports, this volume).

Further confirmation of inimical benthic conditions comes from micropaleontological analysis (site reports, this volume). The presence of a restricted benthic microfauna, i.e., two species of Buliminacea in vertically adjacent core sections, and high-diversity, abundant tropical planktonic assemblages (both foraminifers and radiolaria) tend to corroborate the idea of an organicrich, reducing bottom environment (at slope depths of a few hundreds of meters), in which some oxygen was present, overlain by productive tropical water masses, thereby favoring the second model rather than the third.

The "Hess Archipelago" also may have played some role in providing the nutrients that initiated the plankton blooms. Terrestrial run-off from the islands is indicated by lipids of fern and conifer origin. Certainly, the low amounts of terrestrial plant lipid do not require the 
proximity of major continental areas. Some of the silica, calcium, phosphorous, etc. necessary for plankton nutrition may have been derived from the weathering of vegetated volcanic islands. The association between volcanism, high radiolarian input, and black shale may not be fortuitous, as has been noted (site reports, this volume).

Finally it is necessary to emphasize the restriction of the carbonaceous facies to the Aptian-Albian in this area of the Pacific (as in many other parts of the world ocean). The reasons for the restriction of this event to the Lower Cretaceous and the frequency of algal carbonaceous limestones and "black shales" within the carbonaceous facies will be the subject of subsequent work.

\section{ACKNOWLEDGMENTS}

We thank the Natural Environment Research Council (GR3/2951 and supplement, GR3/3758) for support. J. M., I. D. T., and P. A. C. acknowledge Research Studentships from the Natural Environment Research Council, the Science Research Council, and the British Petroleum Co. Ltd., respectively. We also thank Mr. G. P. Cooles and Dr. S. P. Lowe of the British Petroleum Co. Ltd. for providing the organic carbon determination and palynological analysis.

We are grateful to Mrs. A. P. Gowar and Mr. G. J. Shaw for help with C-GC-MS analyses, to Dr. P. J. Isaacson for assistance in the preliminary sample evaluations, and to Dr. J. K. Volkman for useful discussions.

\section{REFERENCES}

Baker, E. W., Palmer, S. E., and Huang, W-Y., 1978. Chlorin and porphyrin geochemistry of DSDP Leg 40 sediments. In Bolli, H. M., Ryan, W. B. F., et al., Init. Repts. DSDP, 40 (Supplement): Washington (U.S. Govt. Printing Office), 639-647.

Baker, E. W., Palmer, S. E., Huang, W-Y., et al., 1978. Mass and electron paramagnetic resonance spectrometric analyses of selected organic components of Cretaceous shales of marine origin. In Uden, P. C., Siggia, S., and Jensen, H. B. (Eds.), Analytical Chemistry of Liquid Fuel Sources: Washington (Am. Chem. Soc.), pp. $159-180$.

Ballantine, J. A., Williams, K., and Burke, B. A., 1977. Marine sterols. IV. $\mathrm{C}_{21}$ sterols from marine sources. Identification of pregnane derivatives in extracts of the sponge Haliclona rubens. Tetrahedron Lett.:1547-1550.

Barnes, P. J., Brassell, S. C., Comet, P. A., et al., 1979. Preliminary lipid analyses of Core Sections 18, 24 and 30 from Hole 402A. In Montadert, L., Roberts, D. G., et al., Init. Repts. DSDP, 48: Washington (U.S. Govt. Printing Office), 965-976.

Berti, G., and Bottari, F., 1968. Constituents of ferns. In Reinheld, L., and Liwschitz, Y. (Eds.), Progress in Phytochemistry (Vol. 1): New York (Interscience), 589-685.

Berti, G., Bottari, F., Marsili, A., et al., 1963. Structure de l'adiantone, un nor-triterpene naturel. Tetrahedron Lett., 1283-1287.

Bird, C. W., Lynch, J. M., Pirt, S. J., et al., 1971. Steroids and squalene in Methylococcus capsulatus grown on methane. Nature, 230: 473-475.

Boon, J. J., Rijpstra, W. I. C., De Lange, F., et al., 1979. The Black Sea sterol-A molecular fossil for dinoflagellate blooms. Nature, 277:125-127.

Brassell, S. C., 1980. The lipids of deep sea sediments: their origin and fate in the Japan Trench [Ph.D. dissert.]. University of Bristol.

Brassell, S. C., Comet, P. A., Eglinton, G., Isaacson, P. J., et al., 1980. Preliminary lipid analysis of Sections 440A-7-6, 440B-3-5, 440B-8-4, 440B-68-2 and 436-11-4 from DSDP Legs 56 and 57. In Scientific Party, Init. Repts. DSDP, 56, 57, Pt. 2: Washington (U.S. Govt. Printing Office), 1367-1390.

Brassell, S. C., Comet, P. A., Eglinton, G., et al., 1980. The origin and fate of lipids in the Japan Trench. In Douglas, A. G., and Maxwell, J. R. (Eds.), Advances in Organic Geochemistry 1979: Oxford (Pergamon Press), pp. 375-392.
Brassell, S. C., Comet, P. A., Eglinton, G., McEvoy, J., et al., 1980. Preliminary lipid analysis of Core Sections 14,18 and 28 from Hole 416A. In Lancelot, Y., Winterer, E. L., et al., Init. Repts. $D S D P, 50$ : Washington (U.S. Govt. Printing Office), 647-664.

Brassell, S. C., Gowar, A. P., and Eglinton, G., 1980. Computerised gas chromatography-mass spectrometry in analyses of sediments from the Deep Sea Drilling Project. In Douglas, A. G., and Maxwell, J. R. (Eds.), Advances in Organic Geochemistry 1979: Oxford (Pergamon Press).

Brassell, S. C., Wardroper, A. M. K., Thompson, I. D., et al., 1981. Specific acyclic isoprenoids as biological markers of methanogenic bacteria in marine sediments. Nature, 290:693-696.

Cranwell, P. A., 1973. Branched-chain and cyclopropanoid acids in a recent sediment. Chem. Geol., 11:307-313.

Dastillung, M., and Albrecht, P., 1977. $\Delta^{2}$-sterenes as diagenetic intermediates in sediments. Nature, 269:678-679.

Delseth, C., Tolela, L., Scheuer, P. J., et al., 1979. $5 \alpha$-norcholestan$3 \beta$-ol and (24Z)-stigmasta-5,7,24(28)-trien-3 $\beta$-ol, two new marine sterols from the Pacific sponges Terpios zeteki and Dysidia herbacea. Helv. Chim. Acta, 62:101-109.

Eglinton, G., and Hamilton, R. J., 1967. Leaf epicuticular waxes. Science, 156:1322-1335.

Ensminger, A., 1977. Évolution de composés polycycliques sédimentaires [Thesé de docteur ès sciences]. Université Louis Pasteur, Strasbourg.

Gagosian, R. B., and Smith, S. O., 1979. Steroid ketones in surface sediments from the south-west African shelf. Nature, 277:287289.

Gaskell, S. J., and Eglinton, G., 1975. Rapid hydrogenation of sterols in a contemporary lacustrine sediment. Nature, 254:209-211.

Greiner, A. Ch., Spyckerelle, C., and Albrecht, P., 1976. Aromatic hydrocarbons from geological sources. I. New naturally occurring phenanthrene and chrysene derivatives. Tetrahedron, 32:257-260.

Greiner, A. Ch., Spyckerelle, C., Albrecht, P., et al., 1977. Aromatic hydrocarbons from geological sources. V. Mono and diaromatic hopane derivatives. J. Chem. Res., (M):3829-3871.

Hofheinz, W., and Oesterhelt, G., 1979. 24-isopropylcholesterol and 22-dehydro-24-isopropylcholesterol, two novel sterols from a sponge. Helv. Chim. Acta, 62:1307-1309.

Holzer, G., Oró, J., and Tornabene, T. G., 1979. Gas chromatographic-mass spectrometric analysis of neutral lipids from methanogenic and thermoacidophilic bacteria. J. Chromatogr., 186: 795-809.

Howard, D. L., 1980. Polycyclic triterpenes of the anaerobic photosynthetic bacterium Rhodomicrobium vannielli [Ph.D. dissert.]. Univ. of Calif., Los Angeles.

Huang, W. Y., and Meinschein, W. G., 1976. Sterols as source indicators of organic materials in sediments. Geochim. Cosmochim. Acta, 40:323-330.

1979. Sterols as ecological indicators. Geochim. Cosmochim. Acta, 43:739-745.

Lancelot, Y., and Larson, R. L., 1975. Sedimentary and tectonic evolution of northwestern Pacific. In Larson, R. L., Moberly, R., et al., Init. Repts. DSDP, 32: Washington (U.S. Govt. Printing Office), 925-939.

Mackenzie, A. S., Patience, R. L., Maxwell, J. R., et al., 1980. Molecular parameters of maturation in the Toarcian Shales, Paris Basin, France. I. Changes in the configurations of acyclic isoprenoid alkanes, steranes and triterpanes. Geochim. Cosmochim. Acta, 44:1709-1721.

Maxwell, J. R., Quirke, J. M. E., and Eglinton, G., in press. Aspects of modern porphyrin geochemistry and the Treibs' hypothesis. Proceedings of the Treibs Symposium, Munich, 1979.

Ourisson, G., Albrecht, P., and Rohmer, M., 1979. The hopanoids. Palaeochemistry and biochemistry of a group of natural products. Pure Applied Chem., 51:709-729.

Palmer, S. E., and Baker, E. W., 1980. Nickel porphyrins from IPOD Leg 50, Sites 415 and 416. In Lancelot, Y., Winterer, E. L., et al., Init. Repts. DSDP, 50: Washington (U.S. Govt. Printing Office), 643-646.

Palmer, S. E., Huang, W-Y., and Baker, E. W., 1979. Tetrapyrrole pigments from Bermuda Rise: DSDP Leg 43. In Tucholke, B., Vogt, P., et al., Init. Repts. DSDP, 43: Washington (U.S. Govt. Printing Office), 657-661. 
Patience, R. L., Rowland, S. J., and Maxwell, J. R., 1978. The effect of maturation on the configuration of pristane in sediments and petroleum. Geochim. Cosmochim. Acta, 42:1871-1875.

Patterson, G. W., 1971. The distribution of sterols in algae. Lipids, 6:120-127.

Rubinstein, I., Sieskind, O., and Albrecht, P., 1975. Rearranged sterenes in a shale: occurrence and simulated formation. J. Chem. Soc., Perkin I, 1833-1835.

Simoneit, B. R. T., 1977. Diterpenoid compounds and other lipids in deep-sea sediments and their geochemical significance. Geochim. Cosmochim. Acta, 41:463-476.

, 1978. The organic chemistry of marine sediments. In Riley, J. P., and Chester, R. (Eds.), Chemical Oceanography (Vol. 7): New York (Academic Press), 233-311.

Spyckerelle, C., Greiner, A. Ch., Albrecht, P., et al., 1977a. Aromatic hydrocarbons from geological sources. III. A tetrahydrochrysene derived from triterpenes in Recent and old sediments. 3,3,7trimethyl-1,2,3,4-tetrahydrochrysene. J. Chem. Res., (M):37463777; (S):330-331.

1977b. Aromatic hydrocarbons from geological sources. IV. An octahydrochrysene, derived from triterpenes in Recent and old sediments, 3,3,7,12a-tetramethyl-1,2,3,4,4a,11,12,12a-octahydrochrysene. J. Chem. Res., (M):3801-3828; (S):332-333.

Thomson, I. D., Brassell, S. C., Comet, P. A., et al., in press. Preliminary lipid analyses of Cores 49,54 and 59 from Hole 462 . In Schlanger, S. O., Larson, R. L., et al., Init. Repts. DSDP, 61: Washington (U.S. Govt. Printing Office).

Tissier, M. J., and Dastillung, M., 1978. Inventaire et dynamique des lipides à l'interface eau de mer-sediment. V. Hydrocarbures polyaromatiques des sédiments de l'eau de mer et de l'eau interstitielle. Géochimie Organique des Sédiments Marins Profonds Orgon II: Atlantique-N.E. Brèsil: Editions du C.N.R.S., pp. 275-283.

Tissier, M. J., and Spyckerelle, C., 1977. Hydrocarbures polyaromatiques des sédiments. Géochimie Organique des Sédiments Marins Profonds Orgon I: Mer de Norvege: Editions du C.N.R.S., pp. 229-236.

Tissot, B., Demaison, G., Masson, P., et al., 1980. Paleoenvironment and petroleum potential of middle Cretaceous black shales in Atlantic basins. Am. Assoc. Petrol. Geol. Bull., 64:2051-2063.

Triebs, A., 1936. Chlorophyll und Hamin Mineralstoffen. Angew. Chem., 49:682-686.

Wakeham, S. G., Schaffner, C., Giger, W., et al., 1979. Perylene in sediments from the Namibian Shelf. Geochim. Cosmochim. Acta, 44:403-415.

Wakeham, S. G., Schaffner, C., and Giger, W., 1980. Polycyclic aromatic hydrocarbons in recent lake sediments. II. Compounds derived from biogenic precursors during early diagenesis. Geochim. Cosmochim. Acta, 44:415-431.

Wardroper, A. M. K., 1979. Aspects of the geochemistry of polycyclic isoprenoids [Ph.D. dissert.]. University of Bristol.

Wardroper, A. M. K., Brooks, P. W., Humberston, M. J., et al., 1977. Analysis of steranes and triterpanes in geolipid extracts by auto- matic classification of mass spectra. Geochim. Cosmochim. Acta, 41:499-510.

Withers, N. W., Kokke, W. C. M. C., Rohmer, M., et al., 1979. Isolation of sterols with cyclopropyl-containing side chains from the cultured marine alga Peridinium foliaceum. Tetrahedron Lett., 3605-3608.

Withers, N. W., Tuttle, R. C., Holz, G. G., et al., 1978. Dehydrodinesterol, dinosterone and related sterols of a non-photosynthetic dinoflagellate. Crypthecodium cohnii. Phytochem., 17:1987-1989.
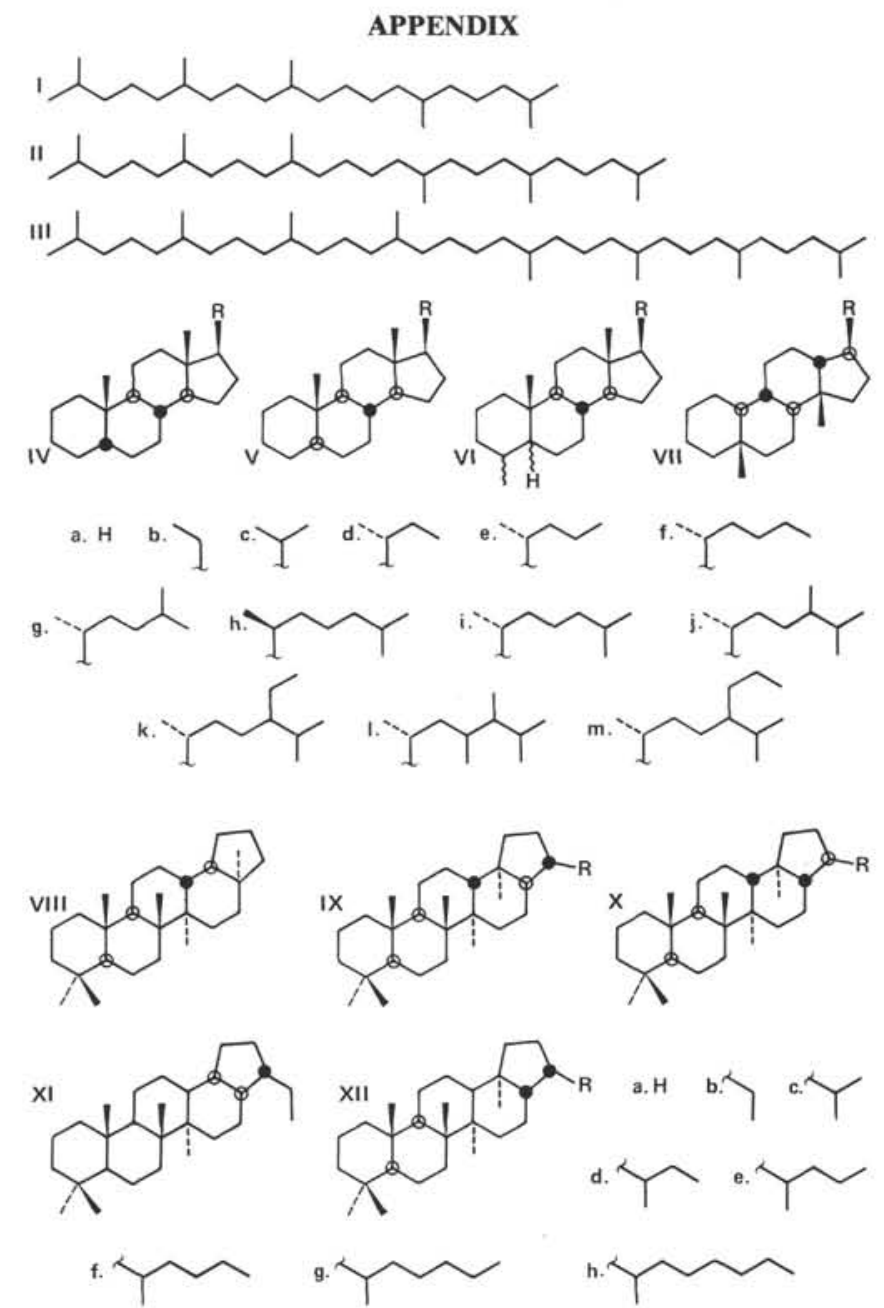


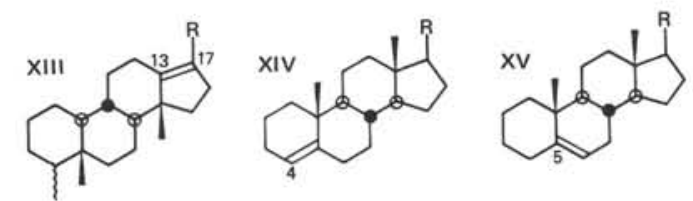

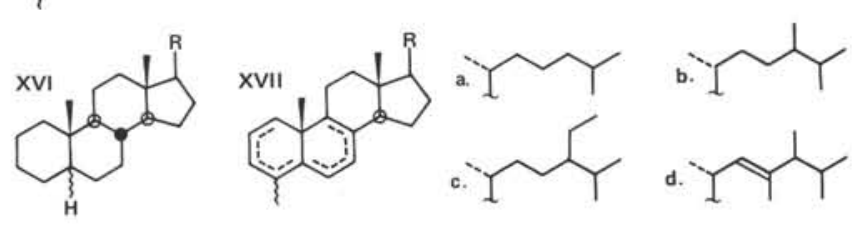
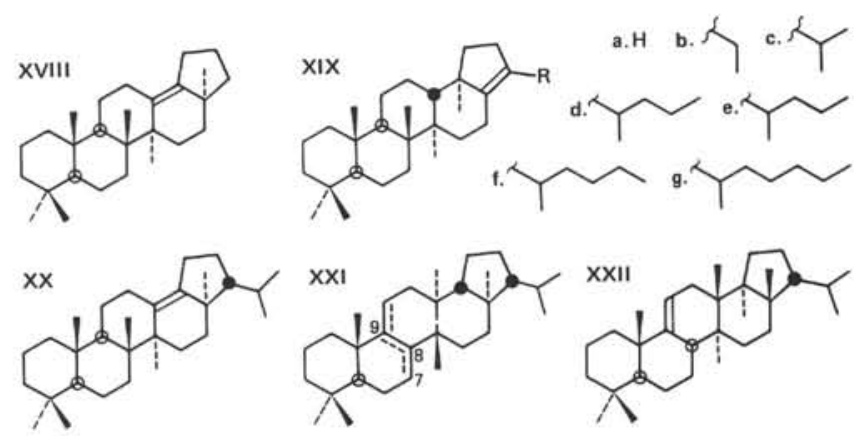

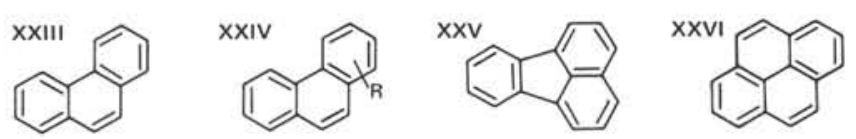

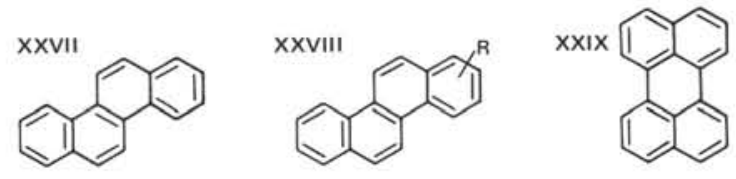

(1)

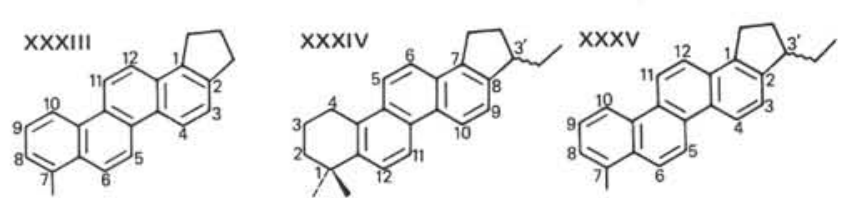

(1)
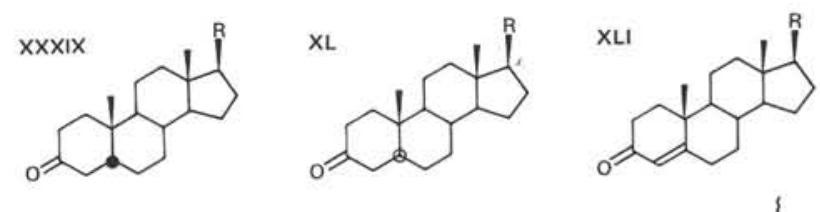

IOC<smiles>CCC(C)C(CC)CC(C)C</smiles><smiles>CC(/C=C(\C)C(C)C(C)C)=C(C)C1CCC2C1CCC1(C)CCC(=O)C(C)CCC21</smiles><smiles>CC1(C)CCCC23CCC4(CCC5C6CCC(=O)C6CC54)CCC12C3</smiles>

XLIV
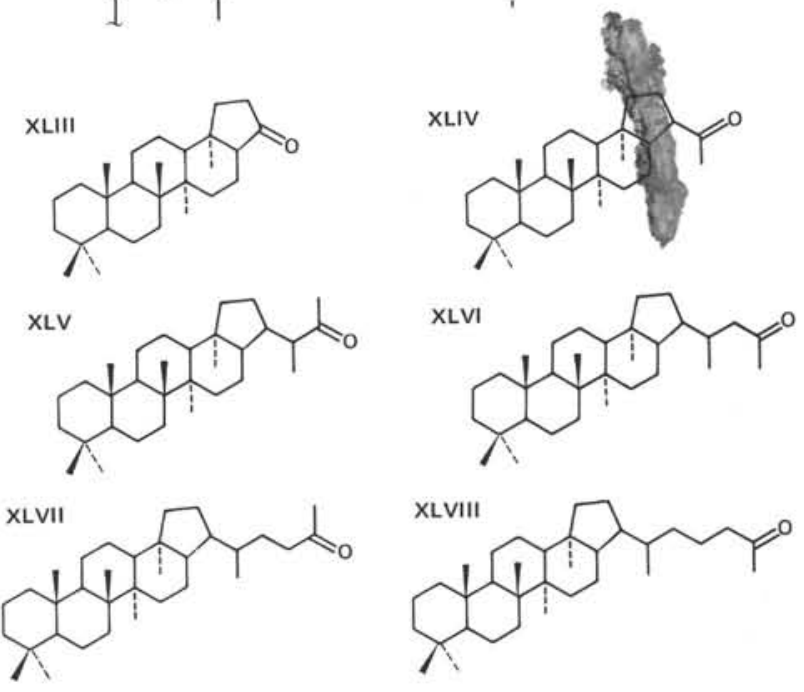

(1)III)<smiles>CC1CCC2C1CCC1CC3CCCCC3CCC12</smiles><smiles>CC1CCC2C1CCC1C2CCC2(C)CCCCC12C</smiles><smiles>CC1CCC2C1CCC1C2CCC2C(C)CCCC21C</smiles><smiles>CC(C)CCCC(C)C</smiles><smiles>CC(C)CCC(C)C(C)C</smiles><smiles>CCC(CCC(C)C)CC(C)CC(C)C=C(C)C(C)C(C)C</smiles>

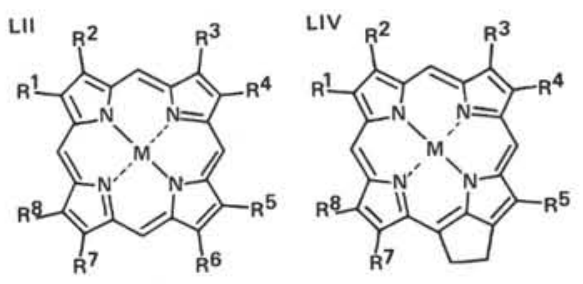

$\begin{array}{lll}\text { a. } M=V \models O & \text { b. } M=N i\end{array}$ 